\title{
Habitar la quebrada: conformación de gradientes en las trazas vernaculares de los sectores altos de Valparaíso
}

\section{Omar Eduardo Cañete-Islas Juan Luis Moraga-Lacoste Felipe Mateo López-Flores Universidad de Valparaíso, Chile Escuela de Arquitectura}

Cañete-Islas, 0. E., Moraga-Lacoste, J. L. \& López-Flores, F. M. (2018). Habitar la quebrada: conformación de gradientes en las trazas vernaculares de los sectores altos de Valparaíso. Revista de Arquitectura (Bogotá), 20(2), 20-35 doi: http://dx.doi.org/10.14718/ RevArq.2018.20.2.106

http://dx.doi.org/10.14718/RevArq.2018.20.2.106

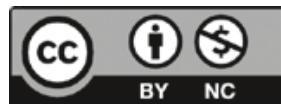

mar Eduardo Cañete-Islas

Psicólogo, Universidad de Valparaíso (Chile)

Magíster en Psicología social, Universidad de Valparaíso (Chile)

Docente Escuela de Arquitectura, Universidad de Valparaíso (Chile). Cátedra de Geometría Fractal; profesor Módulo de Forma en el Taller de Ciudad, carrera de Arquitectura.

(D) https://orcid.org/0000-0003-4762-37/8 ocanetei00@yahoo.es

Juan Luis Moraga-Lacoste

Arquitecto, Universidad de Chile (Chile)

Decano de la Facultad de Arquitectura, Universidad de Valparaíso (Chile)

Participa en investigación de tipo docente para la pedagogía de la asignatura Taller de Arquitectura, especialmente sobre el habitar humano en la ciudad.

(D) https://orcid.org/0000-0002-5226-7773

moraga.juanluis@gmail.com

Felipe Mateo López-Flores

Arquitecto, Universidad de Chile (Chile).

Trabaja en modelación y diseños modulares constructivos y uso de diseño computacional paramétrico. (D) https://orcid.org/0000-000I-5776-7059

\section{Resumen}

La autoconstrucción y los asentamientos espontáneos también pueden considerarse como un factor integrador y cohesionador sociofamiliar con el entorno físico y natural. El estudio de las distintas variables morfológico-territoriales que inciden y delimitan los procesos de crecimiento de la traza urbana, y la densificación y construcción espontáneas, permiten la comprensión de una mejor zonificación y reconocer las interacciones a escala y cómo potencian la emergencia de cualidades de habitabilidad y lugaridad local, o el debilitamiento, deterioro y destrucción de la vida en un lugar. En este sentido, se estudia el sistema de conexión natural entre el denominado camino La Pólvora y el sector del plano-centro de la ciudad de Valparaíso. Como resultado se caracterizan los sectores y se propone la noción de gradiente de densificación que actúa como un criterio para la zonificación territorial, el cual contempla modelos morfológico-dinámicos en la densificación urbana vernacular, con base en gradientes de habitabilidad y necesidad de regulación e intervención en zonas de riesgo.

Palabras clave: asentamientos informales, morfología urbana, patrones de ocupación, periferia urbana, política social, trama urbana.

Inhabiting the ravine: Gradient configuration in the

\section{vernacular layouts of the higher sectors of Valparaíso}

\section{Abstract}

Self-construction and spontaneous settlements can also be considered as a socio-familiar factor that contributes to integration and cohesion with physical and natural environments. The study of spontaneous densification and construction, as well as different morphological-territorial variables that influence and delimit growth processes in the urban layout allow a bette understanding of zoning and a recognition of interactions at scale and how they promote the emergence of habitability qualities and the sense of belonging to a place, or the weakening, deterioration, and destruction of life in a place. In this sense, the paper studies the natural connection system between the so-called La Pólvora road and the flat-center sector of the city of Valparaíso. As a result, it characterizes these sectors and proposes the notion of densification gradient, which acts as a criterion for territorial zoning that contemplates morphologicaldynamic models in vernacular urban densification, based on gradients of habitability and the need for regulation and intervention in risk areas.

Keywords: Informal settlements, urban morphology, occupation patterns, urban periphery, social policy, urban grid.

\section{Habitar a quebrada: conformação de níveis nos traçados} vernaculares dos setores altos de Valparaíso

\section{Resumo}

A autoconstrução e os assentamentos espontâneos também podem ser considerados um fator de integração e de coesão sociofamiliar com o entorno físico e natural. O estudo das diferentes variáveis morfológico-territoriais que incidem e delimitam os processos de crescimento do traçado urbano, e a densificação e a construção espontâneas, permitem a compreensão de um melhor zoneamento e reconhecimento das interações em escala e como potenciam a emergência de qualidades de habitabilidade e lugaridade local, ou a debilitação, a deterioração e a destruição da vida em um lugar. Assim, o sistema de conexão natural entre o denominado caminho La Pólvora e o setor do plano-centro da cidade de Valparaíso (Chile) são estudados. Como resultado, os setores são caracterizados e é proposta a noção de nível de densificação, que atua como um critério para dividir o território em zonas, que contempla modelos morfológico-dinâmicos na densificação urbana vernacular, baseando-se em níveis de habitabilidade e necessidade de regulação e intervenção em áreas de risco.

Palavras-chave: assentamentos informais, morfologia urbana, padrões de ocupação, periferia urbana, política social, tecido urbano.

\section{Introducción}

A partir del proyecto de investigación "Estudios sobre los límites exteriores de las ciudades de Valparaíso y Viña del Mar. Densificación y crecimiento", adscrito a la línea de investigación "Urbanismo, aspectos sociales del habitar", del grupo de investigación Taller de Ciudad, de la Escuela de Arquitectura de la Universidad de Valparaíso, se realizaron estudios de caso donde se aprecien procesos de crecimiento y densificación significativos en los límites exteriores del radio urbano.

En este sentido, y en continuidad con la noción de traza urbana propuesta por Waisberg (1995), los autores postulan la noción de gradiente de densificación, que ha de actuar como un criterio para la zonificación territorial desde una mirada que abarca las zonas exteriores de la ciudad. En el presente artículo se estudia el sistema de conexión natural entre el denominado camino La Pólvora (ubicado en la meseta y actual periferia superior circundante de la ciudad de Valparaíso) y el sector del plano-centro, en su zona inferior del denominado plan histórico de la ciudad. En este caso, se estudia la bajada San Roque desde su conexión con el sector del camino La Pólvora, hasta su empalme con el sector del barrio O’Higgins, y de esta en su conexión con la bajada Washinsgton a la llegada por el sector de la Avenida Argentina, en la entrada al sector de El Almendral, en la parte plana y baja en la ciudad.

La caracterización de estos sistemas de crecimiento urbano vernáculo, en tanto límites exteriores que definen la ampliación actual de la ciudad, son parte de una serie de estudios donde se busca describir y proponer zonas de densificación periférica, como el ya realizado y propuesto para la zona del sector de Rodelillo alto, cercano a la conurbación que une a la ciudad de Valparaíso con Viña del Mar (Moraga, Cañete y López, 2011; 2013). Este crecimiento no se da de manera integral, sino mediante la formación de sucesivas gradientes de habitabilidad, lo que nos permite plantearlo como un criterio estructurador territorial dinámico, que complementa las nociones clásicas de agrupación y traza, por un lado, y, por otro, las nociones de límites exteriores y periferias interiores que se generan producto del asentamiento vernáculo en sus diversos grados de consolidación, lo que permite plantear posibles criterios de uso, densificación y eventual diseño proyectual que respete y potencie dicho crecimiento. 


\section{Límites geomorfológicos del crecimiento urbano en el Valparaíso actual. Del crecimiento y habitar dentro de la quebrada a los sistemas de quebradas en el territorio}

Como es sabido, la autoconstrucción y asentamiento espontáneos, en muchos casos, lejos de ser un elemento desfavorable asociado a la precariedad de las intervenciones, o la ausencia de sistemas urbanizados y redes de instituciones básicas, además del deterioro y la predación urbano-ambiental, ha sido un factor integrador y cohesionador sociofamiliar al entorno físico y natural, que genera fuertes rasgos de arraigo. Como bien señala Pino (2014) en su reciente revisión respecto de los procesos de apropiación y vida vernácula en los diversos sistemas de quebradas de Valparaíso:

El hábitat informal en las quebradas define un modelo urbano de escala familiar y comunitario propio de ellas, que se desarrolla como proyecto familiar y comunitario, como resultado de una exploración, apropiación y construcción del territorio de las quebradas, donde las modificaciones, renovaciones y ampliaciones son proyectos que se engendran y se consolidan desde la práctica social (p. 221).

Más aún, este estudio sugiere que estos sistemas de quebrada permiten compensar procesos de alugaridad, desintegración social y marginalidad, por un lado -e incluso fomentan patrones de habitabilidad propios-, y una urbanización intensiva que, por otro lado, se impulsa inorgánicamente desde las políticas de especulación inmobiliaria (Pino, 2014). En este marco aparece como relevante estudiar y monitorear, no solo el crecimiento familiar y sus redes barriales más cercanas, sino cómo esto permite consolidar relaciones e integrarse al resto de la vida local situada en un territorio más amplio, en especial, con los sectores altos de la ciudad y, en particular, con el anillo límite en que se ha transformado, en nuestro caso de estudio, el denominado camino La Pólvora.

Así, desde el punto de vista territorial, resulta importante estudiar los procesos de crecimiento, no solo al interior de las quebradas ya consolidadas de hábitat vernáculo (con todas sus riquezas y complejidades), sino especialmente en su cima circundante que, a modo de frontera externa de la urbe, domina todo el sistema de conexiones y tramas en diverso grado de consolidación -a través de sus quebradas-, con el plano y resto de la ciudad. De allí la importancia de estudiar el Ilamado camino La Pólvora, como un sistema territorial y morfológico autónomo y complejo.

La zonificación debe entonces ajustarse al territorio y los modos de vida propios, incluso con zonificaciones a escala humana, especialmente en los asentamientos cercanos a las quebradas, con sus cualidades geomorfológicas particulares de arraigo. Los modelos deben considerar, entonces, dos factores: asentamiento humano vernacular y condiciones geomorfológicas particulares.

En este marco, las dimensiones morfológico-territoriales juegan un papel relevante que codetermina el crecimiento espontáneo de la ciudad en sus límites exteriores más altos, que circundan la ciudad y refuerzan su condición actual desde el anillo generado por el camino La Pólvora, y las consecuentes exposiciones a incendios en las épocas estivales que desde allí se generan, como el devastador ocurrido en abril de 2014, que por cerca de una semana afectó a más de tres mil casas y doce mil personas.

Es importante recordar que este límite alto que circunda la ciudad es una urbanización de antiguo camino rural, que la une a la ruta 68 hasta la entrada subterránea al puerto desde Playa Ancha en el sector y acceso norte, por lo que su construcción ha derivado en diversos procesos de transformación planificada, pero también espontánea, y otros semiformales alrededor de la carretera en el límite superior, en una suerte de tensión y disputa con los asentamientos que ya empezaban a consolidarse desde las quebradas, en su crecimiento espontáneo hacia la parte superior. Así esta nueva carretera, en gran parte de su trayecto, se constituyó en un elemento que dividió, acordonó y cercó dicho crecimiento, más que constituirse en un factor cohesionador del mismo. A esto se le agregó el establecimiento de grandes construcciones como la del Complejo Penitenciario a inicio del año 2000, que aún no ha sido abarcado en toda su magnitud e impacto social. Estas transformaciones y alteraciones de distinto orden y complejidad en su extensión han alterado su morfología y la relación inicial con la ciudad. Gran parte de estas se dan, y se han dado, en un contexto de informalidad desde el crecimiento espontáneo, y su invisibilización y negación de las políticas sociales o de imposición e impertinencia de muchas de ellas.

A esto se suman las características propias de los asentamientos urbanos, la mayoría de ellos irregulares y espontáneos, especialmente por sobre la cota 100, delimitada por la Avenida Alemania, que recorre trasversalmente, a modo de anfiteatro, los diversos cerros de la ciudad, y determina una relación de gradiente de densificación y consolidación desde el plan hacia los cerros. Esta forma de asentamiento fue reconocida por la destacada investigadora M. Waisberg (1979), quien la denominó traza urbana. Como señala la autora: "La traza primitiva es el elemento auténticamente patrimonial que conserva Valparaíso, ya que la edificación ha ido sustituyéndose y, en cambio, la traza permanece" (p. 10); esta es definida por "las condiciones geográficas que influyen en el nacimiento de vías que coinciden con los cauces que bajan las quebradas, articulando la planta urbana en el sentido de cerro a mar" (p. 10). 
La estructuración de la traza urbana, en el caso de Valparaíso, hace que se forme una progresiva gradiente de ocupación y densificación que va desde la cima hacia el fondo de quebrada, desde sus laderas. Proceso que, por cierto, no es lineal ni completo, pero sí progresivo, en la medida que se va poblando el cerro: la cima, luego sus laderas, y después, no en todos los casos, parte del fondo de quebrada (dependiendo de la altura y pendiente principalmente). Esto genera una gradiente de habitabilidad vernácula que actúa como eje densificador. Además, entre cotas y laderas surgen caminos "de borde" que unen transversalmente las quebradas, siguiendo una relativa misma altura. En muchos casos, el fondo de quebrada se deteriora, pues, al hacerse menos ocupable, se suele usar como basurero y vertedero, por lo que en muchos casos pierde, no solo su valor de uso, sino que se degrada el terreno, y lo expone a quemas e incendios por el viento que en muchos lugares, especialmente en verano, desciende por las quebradas, como ocurrió en el gran incendio de 2014, y otros que cada temporada estival afectan la región.

Paralelo a lo anterior debe considerarse la conformación de bolsones, sitios eriazos, periferias interiores, o intersticios irregulares en su forma, ubicados en las laderas de los cerros en dirección hacia el fondo, en la medida que avanzan el asentamiento y la urbanización. Se produce así un habitar en la quebrada que se caracteriza por el uso comunitario de las laderas que conforman diversos sistemas de circulación intra y extraquebradas, especialmente entre agrupaciones de vivienda con algún vínculo familiar, que suelen ocupar las zonas medias de las laderas hacia el fondo de quebrada, que aparece como verdadera periferia o límite interior. Otro factor, como destaca Pino (2014), es una suerte de resistencia a la movilidad y vida fuera de la quebrada (en esa atemporalidad de la vida familiar), así como dinámicas de autosustento que se articulan como factores protectores del habitar integrado que allí ocurre.

Se suma como rasgo distintivo la menor cantidad y calidad de los servicios, infraestructura y consolidación urbana, en la medida que se aleja del plan hacia la periferia y la zona superior, y hace contacto con el circundante camino La Pólvora en la zona alta. En términos generales, según Pino (2014): "la movilidad urbana extraquebrada en relación con la trama urbana de la ciudad es considerada por los habitantes como satisfactoria" (pp. 91-92), en la medida que les permite una clara circulación con el resto de la ciudad, especialmente con el plano, y actúa como eje aglutinador o cohesionador de la identidad local respecto de los diferentes modos de vivir cada cerro y quebrada, principalmente por la concentración de bienes y servicios, fuentes de trabajo, comercio y esparcimiento colectivo.
Sin embargo, tal percepción es distinta al valorar la circulación dentro de la quebrada, la cual es dificultosa, agreste y está aún por consolidar, como bien describe la autora, pese a la interioridad y autonomía respecto de la vida familiar-colectiva.

Por el contrario, la relación con el borde superior aún no decanta del todo en el imaginario urbano, salvo en sectores altos de Playa Ancha, o cercanos al sector donde su ubica el complejo cárcel, pero que no han sido estudiados apropiadamente (Oyarzún et al., 1998, 2006). Claramente, este será un factor importante por intervenir, en caso de que el crecimiento, como es de esperar, inunde las zonas de meseta alta, tras el anillo que actualmente constituye el camino y la autopista de La Pólvora.

Debe señalarse que esta gradiente de habitabilidad abarca tanto la formación de límites interiores como exteriores en dinámica interacción; los límites interiores, no solo las laderas aún no habitadas, los bolsones y sitios eriazos, y los fondos de quebradas, donde predominan diversos tipos de vegetación y basurales informales, sino los límites exteriores que definen los crecimientos actuales de la ciudad, están siendo recientemente descritos y estudiados desde algunos aspectos geomorfológicos por los autores en algunos sectores de las zonas exteriores de Valparaíso, en el llamado sector de Rodelillo alto, cercano a la conurbación que une esta ciudad a la de Viña del Mar (Moraga, Cañete y López, 2011, 2013). De este estudio se desprende la noción de gradiente de zonificación, que aparece como un criterio-marco, estructurador territorial, que permite extender y complementar las nociones clásicas de agrupación y traza urbana, así como postular y plantear posibles criterios de uso, densificación y eventual diseño proyectual (Figura 1)

Lo anterior debe forzarnos a pensar la importancia de la relación entre traza urbana vernacular y modos de habitar, como nos recuerda Christopher Alexander, que revisaremos a continuación.

\section{Lenguaje de patrones}

El reconocido arquitecto Christopher Alexander (Alexander, Ishikawa y Silverstein, 1977) plantea la noción de pattern o patrón para definir una configuración arquitectónica identificable que le otorga una cualidad particular al modo de habitar un lugar. Como señala el autor: "Cada problema edilicio concreto tiene un lenguaje. La ciudad, como totalidad, tiene un lenguaje. Y cada pequeña tarea edilicia dentro de la ciudad tiene su propio lenguaje" (p. 272). El modelo tiene las siguientes características: a) concibe el ambiente habitado como una totalidad, b) esta totalidad es una unidad evolutiva que va cambiando según criterios operacionables, y c) se estructura en función de niveles de complejidad. 


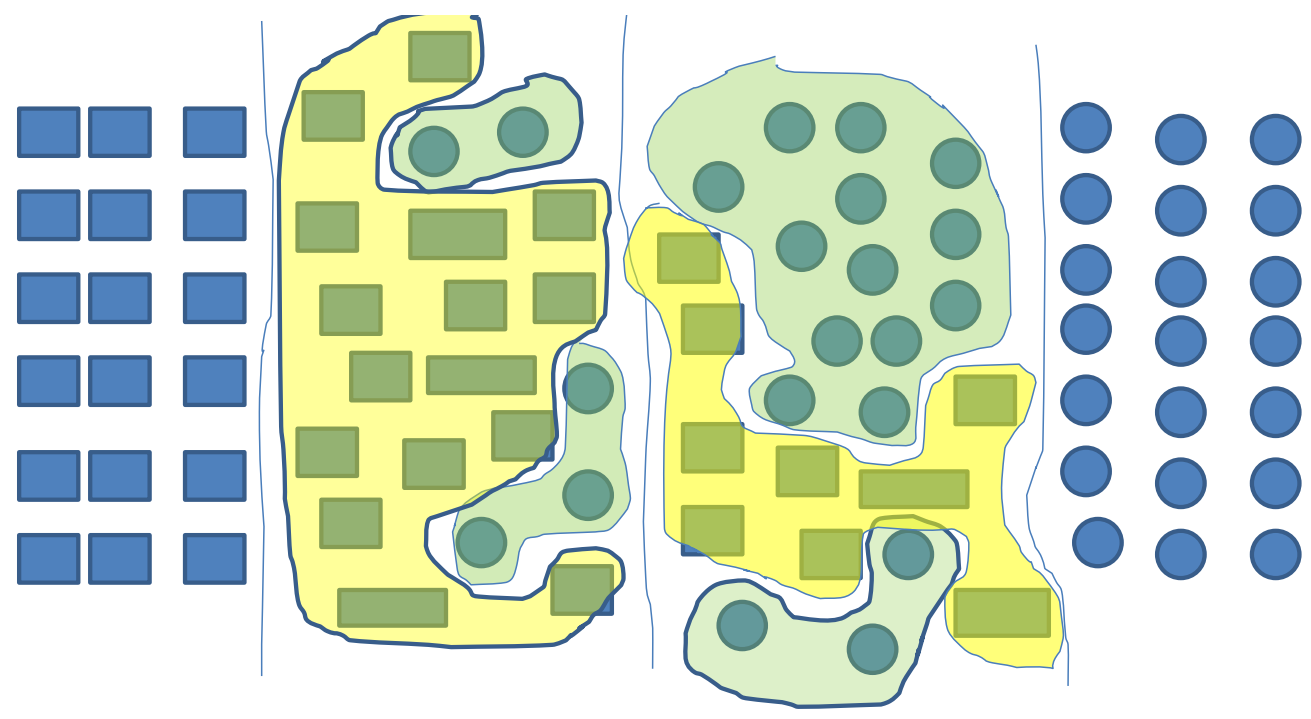

- Figura 1. Un estudio de gradientes permite caracterizar diversas situaciones de interacción, a modo de configuraciones Fuente: elaboración propia, 2017

\section{Totalidad}

El concepto de un medio ambiente total, para Alexander, supone que la arquitectura debe ser pensada holísticamente, donde:

La totalidad no es un criterio extrínseco, sino intrínseco. La totalidad de un sistema [...] supone un proceso de consustanciación con su propia naturaleza, una forma de consistencia propia. Un sistema es total cuando uno lo es consigo mismo, y cuando todas las fuerzas que emergen de su naturaleza exclusiva están equilibradas (Alexander, Ishikawa y Silverstein, 1977, p. 95).

Dicha totalidad presenta las siguientes características: se da de una manera espacial y morfológica, según el ambiente natural de su entorno, el que se incorpora a la morfología del lugar, y pasa a ser casi una extensión integrada natural de ella:

Un medio ambiente total siempre tendrá las características geométricas de la naturaleza. Habrá una variedad infinita, pero cada una de sus partes, a cualquier nivel, será única. Tal como sucede en la naturaleza, esta variedad será de una clase muy simple (como un bosque o un océano tendrá leyes morfológicas de largo alcance, infinitamente repetidas, pero siempre combinadas de diferente manera). Y así como cada hoja y cada ola son irrepetibles, cada lugar será único (Alexander, Ishikawa y Silverstein, 1977, pp. 95-96).

En dicha totalidad, cada lugar se constituye en un medio ambiente propio que expresa la incorporación tridimensional de la cultura que se expresa espacial y geométricamente en todos sus niveles y dimensiones, desde las instituciones hasta las familias e individuos. Es por esto que: "Las diversas formas culturales se expresan en la espacialidad del habitar, por lo que sus diversas categorías quedan siempre definidas en el espacio, y cada una de ellas define una actividad o un lugar o una cosa y sus respectivos comportamientos humanos" (Alexander, Ishikawa y Silverstein, 1977, p. 97).

Pese a su precisión, cada patrón es una imagen fluida, que no violenta la singularidad de los diseños en los cuales aparece, que acepta variaciones, incluso, levemente diferentes, de acuerdo con la manera en que esté combinado con otros patrones.
Por último, cada patrón es siempre aproximativo, la mejor hipótesis: cambiará y mejorará constantemente en forma acumulativa ante el impacto de nuevas evidencias. Así, Alexander (1987) postula que los procesos vernáculos van desde: a) la aparición y configuración de patrones en un lenguaje, b) al embellecimiento de la estructura de patrones, y c) finalmente, la aparición de los embellecimientos de los embellecimientos (valga la redundancia) de los patrones originarios.

\section{Evolución y diseño}

Para que un lenguaje de patrones opere en la realidad debe serlo de forma que todos sus habitantes estén activamente comprometidos en la evolución y en el uso de un lenguaje de patrones compartido. Desde el punto de vista del diseño del habitar, esto trae ciertas implicancias significativas, como preguntarse: "¿Cómo puede evolucionar este lenguaje total, en particular, de manera tal que deje a cada persona en libertad y no sumergida en una masa impersonal de información, sin que la disminuya un sistema que no ha creado"? Esto deriva en que los patrones de este nivel nunca pueden diseñarse o construirse de un solo golpe, sino mediante un crecimiento paciente y pieza a pieza, de tal modo que cada acto individual contribuya siempre a generar esos patrones mayores que, lenta y firmemente, crearán a lo largo de los años una comunidad dotada de esos patrones globales.

Sin duda, esta mirada es muy pertinente desde un punto de vista vernacular, donde lo anterior implica que en la evolución y el diseño de una ciudad, "un lenguaje de patrón debe ser visto como expresión de una forma de vida". Los diversos patrones y sus combinaciones permiten observar, desde la complejidad de la vida, las características mínimas de habitabilidad en las diversas condiciones culturales de una ciudad, y cómo estas se entrelazan para formar un todo, desde lo urbano hasta lo íntimo de cada casa, permitiendo formalizar los criterios de un diseño proyectual, como lenguaje constructivo arquitectónico. 
Metodológicamente, operar desde la multiplicidad de patrones que se enlazan en un diseño proyectual equivale a concebir las relaciones como una red o tejido donde, según Alexander (1977), "un lenguaje de patrones presente una verdadera estructura de malla" (p. 12), donde la red es: "como secuencia, que va a través de los patrones, avanzando siempre desde los niveles mayores hacia los menores, desde los que crean estructuras a los que embellecen esas estructuras y después a los que embellecen los embellecimientos" (p. 12). De esta manera: "la secuencia debe captar toda la envergadura de la malla completa; siguiendo una línea que se hunde para subir de nuevo, en una trayectoria irregular, un poco a la manera de una aguja que recorre una urdimbre" (p. 13).

\section{Dimensiones proyectuales del modelo de Alexander}

Proyectualmente, el estudio de estas relaciones entre patrones es, en buena medida, independiente del diseño mismo, pues diversos diseños pueden satisfacer o no los patrones definidos. Esto da pie para el desarrollo creativo de modelos que sean capaces de integrar cualidades de habitar, a las que debe responder y ajustarse. Como señala Alexander:

Cada lenguaje de patrones, del lenguaje más amplio, puede, [...] contribuir al surgimiento de todos los demás patrones. Recordemos que cada patrón de un lenguaje está vinculado a los patrones que están por encima y por debajo de él. Así, por ejemplo, el patrón de terraza privada a la calle, ayuda a completar los patrones más amplios de la calle: calles verdes, jerarquía de espacios abiertos y terrenos comunes. Aquel es completado a su vez, por los patrones más pequeños que están por debajo de él en el lenguaje: habitación exterior, muro semi-abierto, ladrillo y baldosín blandos (Alexander, Ishikawa y Silverstein, 1977, p. 275).

Así, "cada lenguaje arrastra la estructura del lenguaje más amplio, llevando consigo a otros patrones más amplios y contribuyendo así a componer el todo más amplio" (Alexander, Ishikawa y Silverstein, 1977, p. 275). Por lo mismo, "dentro del lenguaje más amplio es imposible que un acto no contribuya a formar el todo más amplio. Es imposible que un acto de construcción ocurra como un factor aislado; siempre se convierte en una porción de actos que contribuye a mantener el todo" (p. 275).

Este mecanismo de integración de niveles se da por una superposición (overlaping) de patrones, que articula nuevas configuraciones, lo que supone un traslape funcional en las nuevas unidades emergentes fruto de las interacciones entre patrones cuando interactúan. Por ende, desde el punto de vista del diseño proyectual, implica identificar, aprender y modelar estos traslapes, en tanto constituyen un fundamento de la constitución del tejido urbano. En el caso particular de Valparaíso, la descripción que realiza Waisberg (1995) respecto de las trazas, calza muy bien con este modelo.
Niveles de complejidad morfológica en el lenguaje de patrones

Alexander (1977) define tres niveles entendidos dentro del continuo de una ciudad, que abarcan desde lo urbano hasta la casa individual, y pasan por el nivel barrial intermedio. Cada nivel agrupa diversos patrones según ciertos criterios que sirven para unir o conectar los niveles y patrones entre sí. Esto se resume en los siguientes niveles:

Nivel 1: lenguaje que define una ciudad o una comunidad. Son características globales que definen y describen una ciudad o comunidad en su entorno más amplio.

Nivel 2: define y da forma a grupos de edificios y a edificios individuales sobre el terreno o en tres dimensiones vistos como una unidad. Este nivel corresponde a los patrones que pueden diseñarse o construirse que definen los edificios individuales y el espacio entre ellos, y, por ende, trata de patrones que están bajo control de individuos o pequeños grupos, con capacidad para construirlos de una vez.

Nivel 3: lenguaje de patrones que definen y dan forma a los detalles de la construcción. Este nivel es el que permite integrar los espacios o esquemas aproximados de cada edificio con la idea o filosofía del arquitecto o constructor, y está con el contexto social al cual se encuentra orientada o destinada la construcción.

En los últimos años, tanto Alexander como Waisberg han evolucionado en dos tipos de modelos de trabajo, buscando articular una formalización teórica, tanto a) ingenieril-urbanística por un lado, como: b) proyectual-arquitectónica por otro. Estos desarrollos corresponden a:

Modelos de transformación urbana. Los códigos generativos (Alexander, 2005a, b, c; 2006, Alexander, Solomon, Anninou, Clarke y Wall, 1987; Alexander y Schmidt, 2005).

Modelos de interacción entre patrones. Teoría de red urbana (Salingaros, 1999, 2000, 2005, 2007, 2008).

En este sentido, los códigos generativos corresponden a los diversos patrones, organizados como lenguaje -en jerarquías de complejidad morfológica en el territorio y lugar-, son la base proyectual de una lectura comprensiva y compositiva arquitectural. La unión y el enlace de estos patrones individuales y conectados según atributos o sentido proyectual (planificados o vernáculos) producen lo que Alexander (2004, 2005a, 2005b y 2005c) denomina un código generativo, que queda definido como:

. un sistema explícito de pasos, [donde] "se define el producto final, no solo por medio de la especificación del final del producto en sí mismo, sino por medio de la definición de pasos que puedan ser usados para enriquecer el producto final [...]. Estos son, para ser más precisos, códigos que son capaces de conducir, o guiarnos, en 

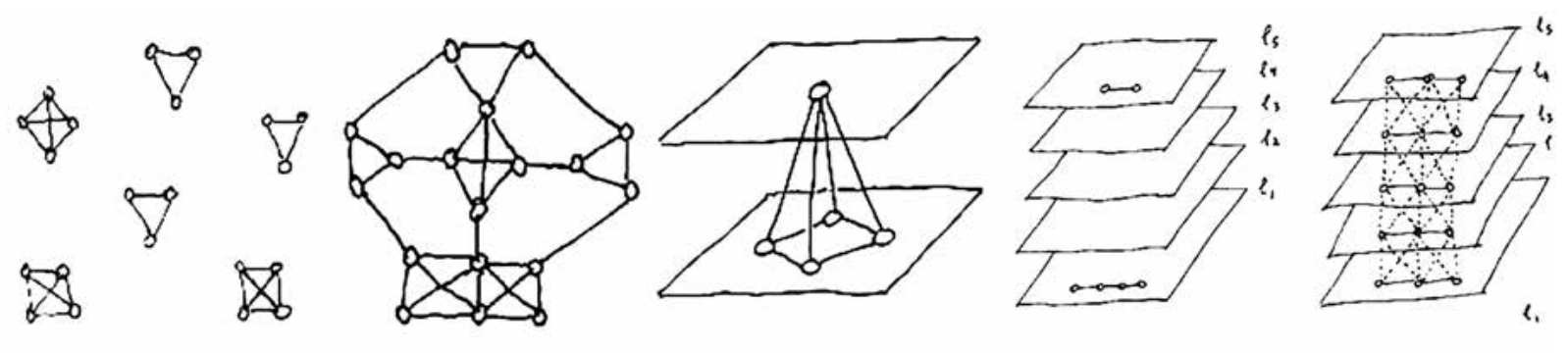

(4igura 2. Modelo general de interconectividad jerarquizada de redes y nodos

Fuente: Salingaros (2000, p. 8). Citado en Cañete Islas (2017a, p. 8.).
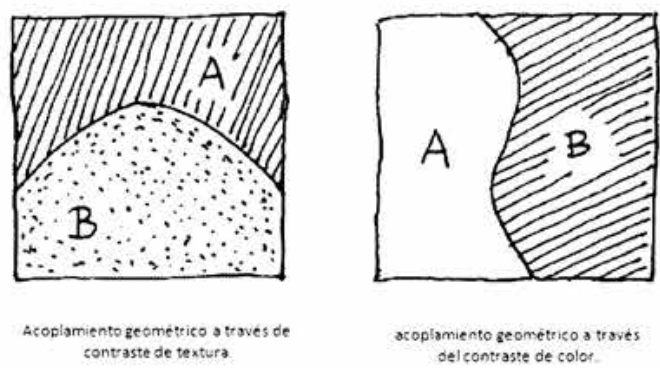
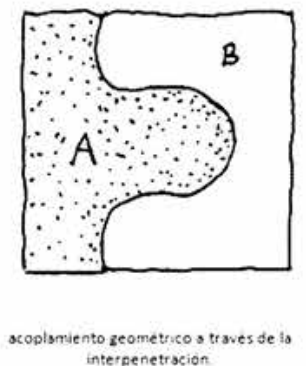

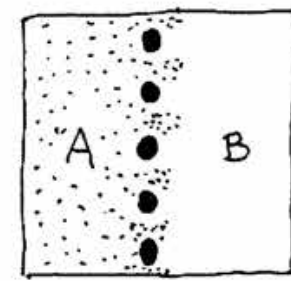

de lo oerme seilitad
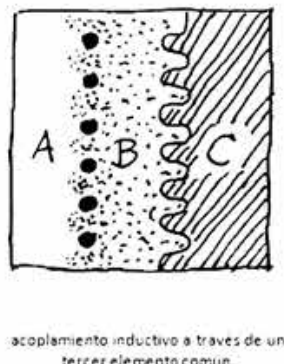

tetcer cienentocomun el orgánico desenvolvimiento de un vecindario [...] Es necesariamente dinámico. Este especifica cualidad de los procesos, que están sucediendo en una variedad de tipos de control, los cuales contribuirán a un adecuado desenvolvimiento del todo, y delinearán la interacción de la gente conectada, de tal manera, que sus resultados puedan, con buena fortuna, llegar a ser un vecindario habitable (2002, p. 25).

Formalización morfológica del lenguaje de patrones. Los aportes de Nikos Salingaros y los modelos en red

Tomando como referente la propuesta de Alexander (1977) de una articulación modular-jerárquica entre patrones, Salingaros (1999, 2000, 2005) intentará poner en marcha estos desarrollos, definiendo algunas propiedades con base en su Modelo de Red Urbana. Estas propiedades son: a) conexiones y conectividad de jerarquías, b) la coherencia global de la jerarquía en red, y c) la jerarquía fractal de la red, mediante la formación de tramas locales (path) con base en entramados que integran escalas mayores y menores (a modo de urdimbre o tejido). Desde el punto de vista de la interconectividad general de redes, Salingaros (2000) propone un modelo general como se expresa en la Figura 2.

Desde un punto de vista particular, para nuestro estudio interesará, en cada caso, evaluar cualitativamente las interconexiones específicas entre distintos tipos de niveles, no necesariamente vinculados jerárquicamente de modo directo, pero que pueden amplificar las relaciones y la fuerza entre ellas, lo que en cierto nivel de complejidad puede ser descrito con un solo tipo de patrón desde otro nivel de jerarquía. Esto puede verse vinculado a más de un patrón correlativo o existente, o tener más o menos fuerza debido a este tipo de saltos y aumento o disminución de redes entre escalas. Esto se resume en las siguientes situaciones que identifica el autor (Salingaros, 1999, 2000, 2007) (Figura 3).

De esta manera, un estudio de gradientes nos permitirá comprender parte de la interacción de complejidades en diversos planos y niveles de representación dinámica.

\section{Complejidad organizada y habitar}

Lo anterior nos permite hablar desde la generación de modelos locales, propios de la complejidad y los rasgos del crecimiento vernacular en Valparaíso, de lo que Alexander y Salingaros denominan una complejidad organizada (ver Morin, 2000; Alexander, 2002, 2004, 2005a, 2005b, 2005c; Cañete, 2017a), que va desde los asentamientos uni y multifamiliares, a las agrupaciones, y de estas a la formación de trazas que interactúan, no solo densificando, sino estableciendo criterios organizativos desde la cima a la quebrada, y se ramifican hasta ir cerrando el espacio, donde quedan intersticios y lugares sin ocupar en este proceso, y gatillan una relación entre periferias interiores y exteriores. Como señala Salingaros (2000), la arquitectura y la planeación urbana pueden:

\begin{abstract}
... ser entendidas como un proceso que incrementa el grado de complejidad organizada. Se ha escrito mucho acerca de la organización de la complejidad, especialmente desde el punto de vista biológico. La complejidad se genera cuando ocurren diferentes procesos al mismo tiempo; y si están organizados coherentemente, dan como resultado una complejidad organizada. Cuando ocurren pocos procesos, la situación no es suficientemente compleja para empezar. Si por otro lado, existe complejidad pero está desorganizada, nos enfrentamos a una situación caótica. Esta situación es incomprensible para la mente humana, porque va más allá de nuestras habilidades perceptivas (p. 9).
\end{abstract}

\section{Ponderación del modelo}

En primer término, las consideraciones antes referidas no anulan el hecho de que la delimitación e identificación de un patrón, y sus límites morfológicos, requiere de una cualificación que dé cuenta de su carácter de lugaridad, habitabilidad y conectividad con otros patrones, además de la potencialidad y apertura para nuevas conexiones, que le otorguen fuerza, consolidación a la red, o, por el contrario, la debiliten, deterioren o desintegren. Por otro lado, las conexiones entre patrones no necesariamente se articulan sobre la base de una discontinuidad morfológica articulada en su
(A) Figura 3. Esquemas de acoplamiento textural capaces de articular una gradiente y continuidad global dentro de una discontinuidad morfológica local

Fuente: Salingaros (2007). 
contigüidad. Es importante destacar la dimensión cualitativa y práctica que permite el lenguaje de patrones, en tanto marco teórico comprensivo, pues dimensiones como la conectividad (con diversos grados de jerarquización y fuerza entre las conexiones y niveles según sea el caso) o la coherencia morfológica de la red con la práctica social y modos de habitabilidad, deben ser considerados como marcos cualitativos y comprensivos. Por ejemplo, Salingaros (2000) describe la siguiente situación:

Muchos patrones sociales de la vida familiar, tales como sentarse alrededor de una mesa, una comida, niños jugando con juguetes en el suelo, las plantas que crecen en macetas grandes, cocinar al aire libre en una parrilla de carbón, etc., pueden ocurrir en un balcón solo si es por lo menos de seis pies (2 metros) de profundidad. Cuando un balcón se hace muy estrecho con el fin de seguir algunos cánones de diseño arbitrario o simplemente para ser barato (lo que satisface los criterios de coherencia interna), no se conecta a los modelos sociales anteriores. Relación en este caso significa el alojamiento y la inclusión entre los patrones pertenecientes a dos lenguas diferentes (p. 10).

En los sectores altos de la ciudad de Valparaíso, un patrón descrito -como la vista al horizontepermite rescatar la condición de anfiteatro natural, que se conjuga con otros patrones como ver una cascada de tejados, la mirada a la quebrada, entre otros, interconectados con la existencia de huellas y senderos, acceso fácil a lugares naturales, pequeñas actividades microeconómicas relacionadas con el entorno natural, como las que describe Andrea Pino en su completo trabajo. Estas configuraciones que articulan el tejido urbano pueden ser alteradas por intervenciones como las carreteras de alta velocidad que impiden acceso peatonal a zonas tipo miradores naturales previamente existentes, el uso de sectores aledaños, transformándola en botadores de basura, con la consecuente proliferación de sitios eriazos, que configuran verdaderas heridas en el paisaje urbano, etc. A este tipo de irrupción de intervenciones destructivas o debilitadoras de la jerarquía y redes entre patrones Salingaros (2000, 2005, 2007) la denomina genéricamente "virus" (Salingaros, 2004), apelando a la metáfora informática.

Por otro lado, deben considerarse aspectos críticos a la hora de ponderar el modelo general, como el relativo al concepto de fuerza frente a cercanía en la relación jerárquica entre patrones. Para Salingaros (2007), la fuerza del patrón parece estar en buena medida asociada a la dependencia jerárquica, asumiendo que la cercanía entre niveles le da fuerza a la conexión. Esta situación bien pudiera contener algún grado de sesgo de la concepción escalonada de niveles, en tanto en nuestra apreciación muchas veces ocurren, como el Alexander (1981) describe cualitativamente, pliegues, solapamientos, gradientes y nudos entre niveles, así como en una urdimbre una hebra sube y baja por entre una tapiz, y solo se muestra evidente en tanto participa del diseño global de la configuración. En este sentido, debiera al menos evaluarse en algunos casos, modularmente, en qué medida la geometría de una jerarquía es afectada por verdaderos pliegues y nudos (no solo nodos) entre niveles jerárquicos. Por ejemplo, en la situación antes descrita, la condición de anfiteatro y mirador natural que la bahía de Valparaíso ofrece (nivel 1), desde distintas alturas o cercanías, tendría una alta fuerza y pregnancia, hasta cierto punto, independiente de la distancia jerárquica con otros niveles, con los cuales haga conexión un patrón concreto (p. ej., almorzar al lado de la ventana) (nivel 3), lo que produciría relaciones secundarias entre jerarquías. Esto, además de las diversas lejanías o cercanías jerárquicas, según sea el caso, de los distintos subniveles entre cada jerarquía. En este punto, en la obra de Alexander es rescatable, en tanto modelo general, lo que denomina diversos criterios de agrupación, interacción o afinidad entre patrones, dentro o entre cada uno de los niveles. Por cierto, creemos que esta dualidad es más bien una fortaleza que una debilidad, en tanto se sea capaz de integrarla efectivamente, según criterios de sentido, pertinencia y relevancia proyectual.

También destaca el caso de los path en Valparaíso, que pueden asemejarse en buena medida al estudio interconectado entre variables geomorfológicas (trazas, vientos, sistemas de quebradas-cerro), por un lado, y unidades y variables de densificación y urbanización (agrupaciones de viviendas, servicios, etc.), por otro. De la revisión existente se destacan los elementos de interés territorial geomorfológico que se describen a continuación.

Otro elemento morfológico característico de los procesos de crecimiento y densificación sson las llamadas agrupaciones de vivienda, que se suelen organizar en gradientes y texturas, pudiendo identificarse diversos path en este sentido, que se desprenden morfológicamente por las laderas, y conectan la cima y sus trazas con los fondos de quebrada.

Similar situación presentan los diversos caminos y huellas que conectan viviendas y calles en los sectores altos de Valparaíso, a partir de los principios de la traza descritos por Waisberg (1995) siguiendo las alturas de las cotas como ejes de mayor densificación, las que a su vez se van orientando desde y hacia las laderas y los fondos de quebrada, para conformar ejes secundarios y terciarios (laderas o lomas que se interceptan) de circulación y encuentro. Estas pueden engarzarse en la formación y el desprendimiento de agrupaciones que prolongan la traza hacia las laderas de los cerros, como parte de una misma red. Estas agrupaciones suelen estar conectadas, no solo por el camino de cima, sino mediante un sistema de huellas intraquebradas (Pino, 2014) 

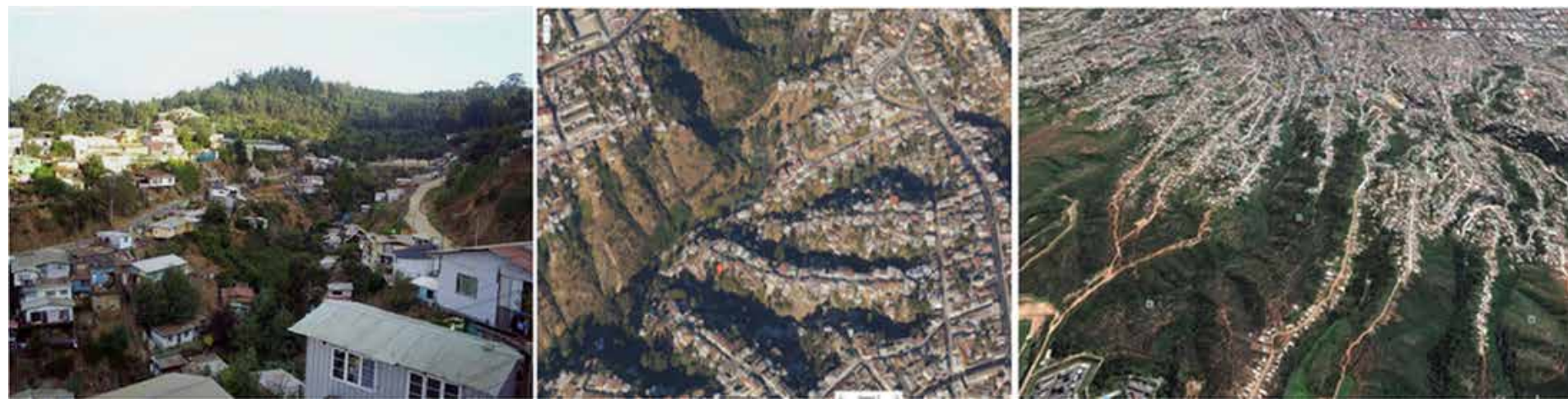

conectando las agrupaciones de laderas que rodean los fondos de quebradas.

Finalmente, debe mencionarse que estos sistemas de crecimiento espontáneo y de apropiación del lugar suelen derivar, a modo de externalidad, en la formación de microbasurales y un deterioro del fondo de quebrada y su vegetación, e incluso micro-ecosistemas que allí existen, pese a que en algunos casos se han observado sistemas de cultivo, extracción a pequeña escala, esparcimiento y mejor cuidado de dichos lugares por parte de quienes allí habitan, con rasgos rur-urbanos. Se debe destacar que justamente este deterioro del fondo de quebrada aparece como un factor de riesgo en la generación de incendios, dados los cauces de viento que se forman, especialmente en épocas de verano, dentro de las quebradas. Por lo mismo, estudiar los aspectos geomorfológicos en relación con los procesos de crecimiento espontáneo (integración niveles I y III del modelo de Alexander) es una prioridad (Figura 4).

\section{Metodología}

Desde el punto de vista de los objetivos del estudio, lo anterior debiera reflejarse en unas zonas dentro de la gradiente de habitabilidad (descripción y caracterización geomorfológica en el territorio). Para esto se proponen los siguientes pasos:

\section{Caracterización del lugar: habitabilidad y asentamiento vernacular}

Históricamente, la población de los cerros en Valparaíso ha ido desde el plan hacia los cerros, siguiendo usualmente huellas que subían por las cimas primero, y desde ahí se desprendían en agrupaciones multifamiliares que ocupaban luego las laderas de quebradas en dirección hacia el fondo de quebrada, densificándose y formando sistemas de huellas intraquebradas $y$, en no pocos casos, sistemas que podrían definirse como rur-urbanos y de formas de autosubsistencia precarias, pero relativamente autónomas respecto del resto de la ciudad (Pino, 2015). Waisberg (1995) ya había descrito este modo de apropiación en función de la noción de trazas, que permitía comprender genéricamente este proceso. Un segundo eje de densificación quedó dado a comienzos del siglo XX, con un gran camino longitudinal que se desarrolló a la altura de la cota 100, conocido como Avenida Alemania, y que operaba como límite y cordón exterior superior de la ciudad. Gran parte de la urbanización de los cerros siguió luego consolidando entre este camino y el sector inferior conocido como el plan; las zonas superiores a esta cota se dejaron a la densificación espontánea, que sigue el mismo patrón vernáculo descrito por Waisberg (1995). Recién en el año 2000 se consolida un segundo camino y autopista que circunda la cima o más alta meseta del anfiteatro natural de la bahía, con el uso de un antiguo camino rural conocido actualmente como La Pólvora. Ambos caminos operaron como anillos y marcaron límites exteriores, y surgen como formas de ordenamiento del crecimiento de la ciudad, $y$, en un sentido amplio, regulan unificando (como grandes anillos periféricos) los sistemas de quebradas que se densificaron, de manera principalmente espontánea, durante casi todo el siglo XX. En algunos casos, la densificación espontánea ha llegado a la misma cima, como en sectores de Playa Ancha y aledaños a la cárcel. En otros casos, tal densificación continúa en diversos grados de consolidación. Su precariedad ha sido reiteradamente constatada con los últimos incendios, que han arrasado con estas poblaciones en diversas quebradas, entre tales caminos longitudinales, y vueltas a levantar y construir por sus propios habitantes. La mayor parte de estas densificaciones no han sido estudiadas, ni se han desarrollado planes de mitigación o habilitación urbana.

\section{Resultados}

\section{El sector del camino La Pólvora. Rasgos generales del lugar}

En los últimos quince años, el sector del camino La Pólvora progresivamente se ha transformado, desde un camino poco transitado, de tierra, boscoso y rural, que rodeaba el sector alto de la ciudad, a una de las principales vías de acceso a la ciudad, especialmente los camiones que transitan con carga de exportación hacia al puerto (provenientes desde la zona centro y centro-sur
(A) Figura 4. A partir del sistema de trazas principales se desprenden y engarzan huellas secundarias y diversos sistemas de agrupaciones de viviendas que ocupan las laderas de la quebrada Fuentes: Google earth, 2017 


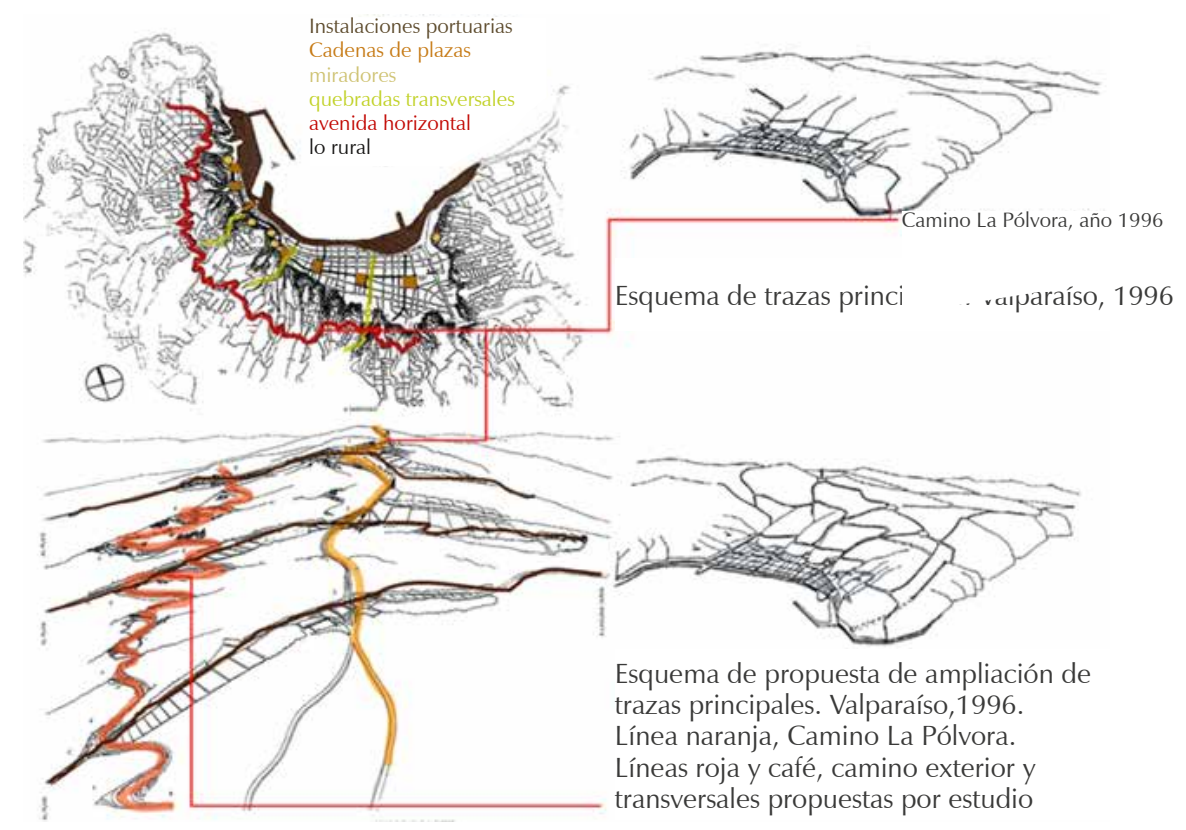

(A) Figura 5. Plano Valparaíso, año 1996. Propuesta de intervención sector alto de Valparaíso Fuente: Oyarzún, Arancibia y Galdámez et al. (1998, 2006).

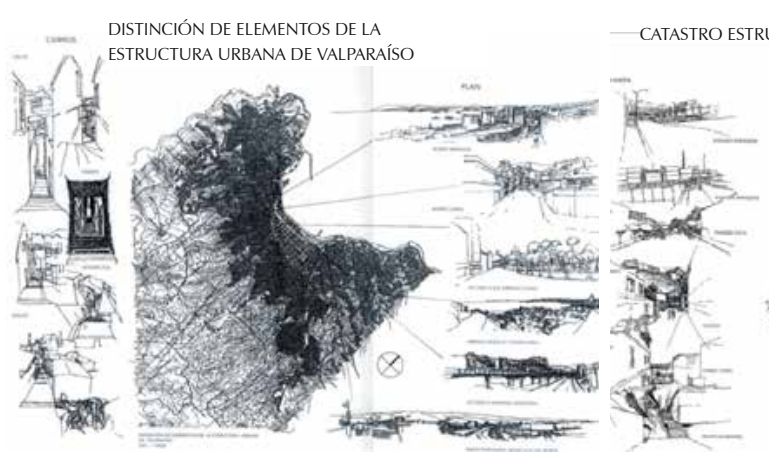

(4) Figura 6. Elementos de estructura del tejido urbano Fuente: Oyarzún et al. (1998).

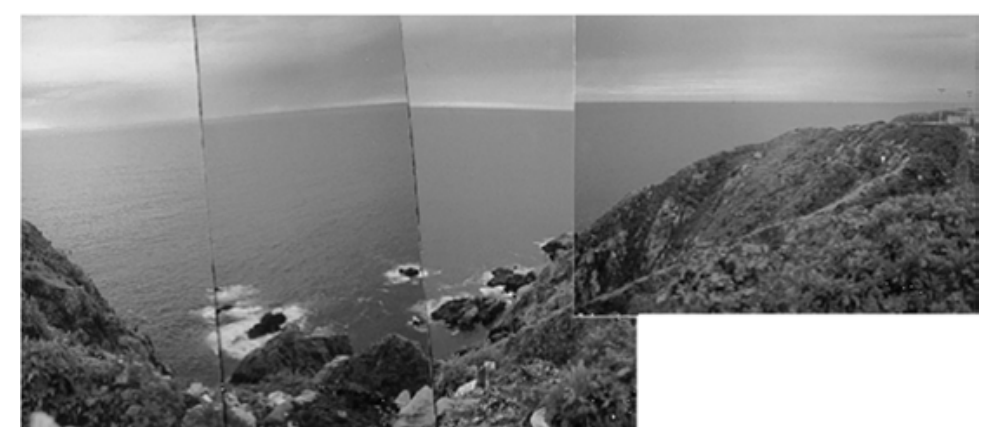

(4) Figura 7. Vista antiguo camino La Pólvora, sector acantilado, Playa Ancha, año 1996

Fuente: Oyarzun, Arancibia y Galdámez et al. $(1998,2006)$.
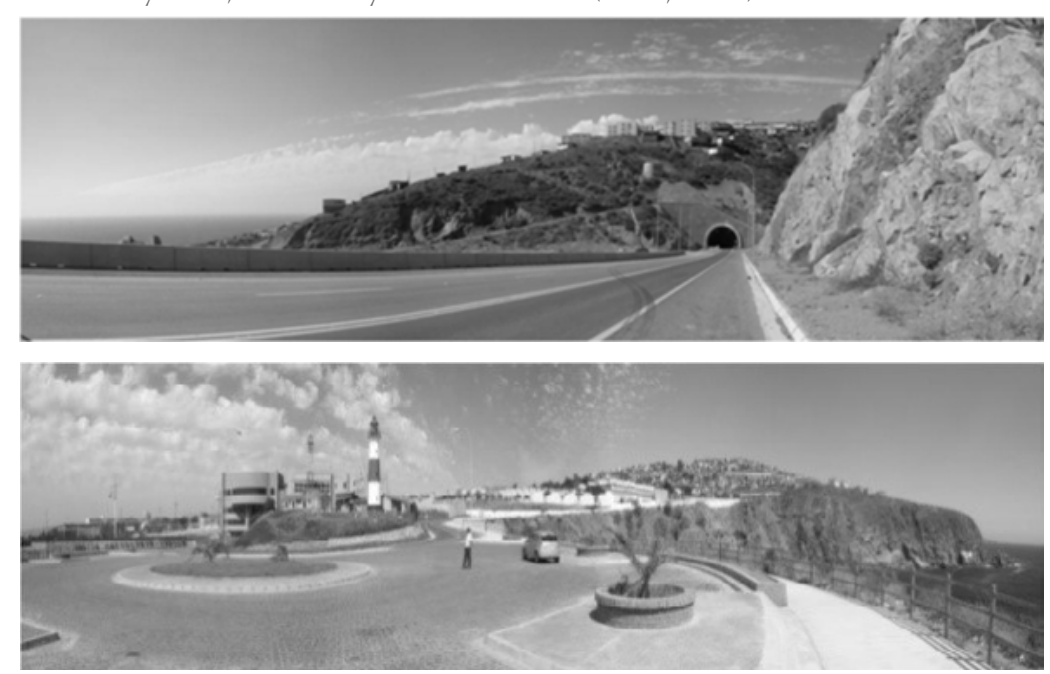

(A) Figura 9. Camino La Pólvora, vistas en diversos años. Vista entrada acceso (A) sur, Playa Ancha, años 1996-2006 (cuando se entregan túneles de acceso construidos)

Fuente: Oyarzun, Arancibia y Galdámez et al. (1996, 2006). del país), vía túneles que empalman el sector alto de Playa Ancha con su zona portuaria. Hacia el año 1996, la Escuela de Arquitectura de la Universidad de Valparaíso desarrolló una propuesta de intervenciones en lugares adyacentes al remodelado camino La Pólvora, a fin de dar coherencia y continuidad urbana a esta nueva súper carretera. Para esto proponía accesos transversales que conectaran a las calles ya existentes que bajaban hacia el plan de la ciudad, así como un camino paralelo a La Pólvora, pero que recuperara y conecta con el centro de Valparaíso. Esta propuesta académica fue presentada en la Bienal Internacional de Arquitectura de 1998, en Barcelona (ver Oyarzún et al., 1998) (Figuras 5 a 11).

Desde un punto de vista terminológico, este estudio se ubica dentro de lo que Alexander denomina el nivel 1 de su sistema de lenguaje de patrones, denominado genéricamente: "Nivel de lenguaje que define una ciudad o una comunidad". Teniendo en cuenta este nivel, y tal como se aprecia en las cartografías y fotos satelitales (imagen 12) existe actualmente una verdadera gradiente de densificación morfológico-territorial desde el plano hacia el sector del camino La Pólvora en la parte alta (imágenes 20-24).

\section{Identificación territorial general del sector}

Desde un punto de vista territorial (nivel 1 según el modelo de Alexander), este puede verse en las fotografías aéreas de la Figura 12.

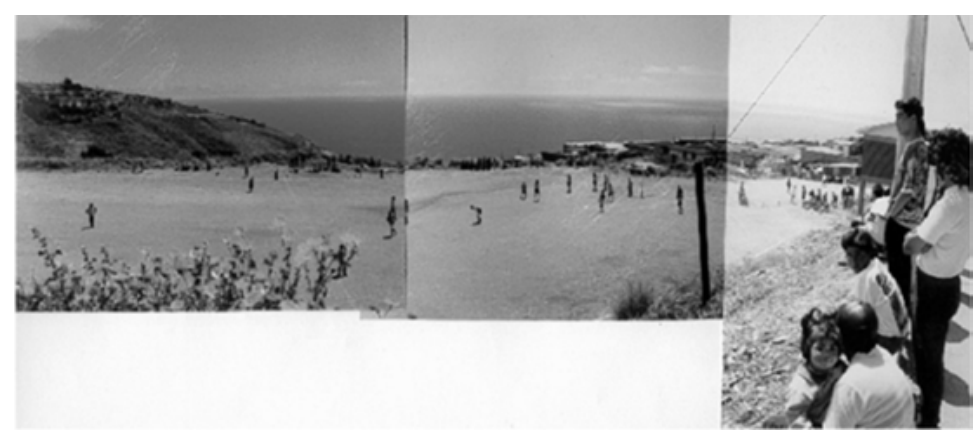

(4) Figura 8. Vista antiguo camino La Pólvora, sector acantilado, Playa Ancha, año 1996

Fuente: Oyarzun, Arancibia y Galdámez et al. (1998, 2006).

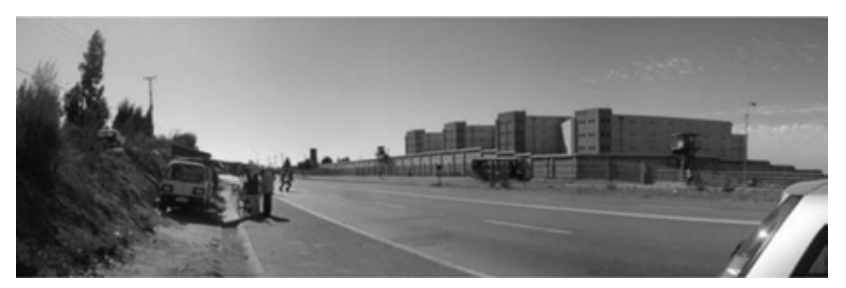

(4) Figura 10. Sector la cárcel, vista desde el camino La Pólvora, año 2006

Fuente: Oyarzun, Arancibia y Galdámez et al. (1998, 2006).

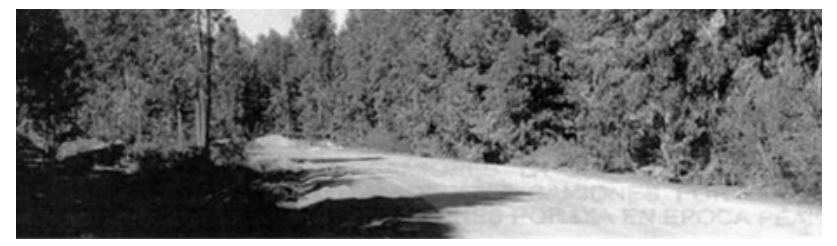

(A) Figura 11. Antiguo camino La Pólvora. Vista camino rural año 1996 Fuente: Oyarzun, Arancibia y Galdámez et al. (1998, 2006). 


\section{Descripción cualitativa del sector de estudio. El caso del camino La Pólvora desde la bajada San Roque}

El sector de estudio corresponde a la bajada natural producida desde el sector de cerro San Roque. Este camino conecta a La Pólvora, en la parte superior de Valparaíso, con el sector del barrio O'Higgins, y a través del mismo, con los cerros aledaños de Santa Helena, Ramaditas, Rocuant y Cuesta Colorada, hasta empalmar directamente con la Avenida Argentina, en la entrada norte a Valparaíso desde la ruta 68 de Santiago. En su camino de descenso hacia la ciudad, luego de diversas conurbaciones entre fundos y bosques, progresivamente se observa el poblamiento espontáneo y vernáculo en laderas y bordes adyacentes a alguna cima, donde se privilegia la existencia de diversas agrupaciones de casas, en la medida que la morfología lo permite. Resulta relevante destacar que en esta primera zona, dominada aún por manchones de bosques y caminos rurales de tierra que se desprenden de la bajada principal, destacan las agrupaciones ubicadas en algunas laderas, y no la existencia de trazas o hileras de casas que siguen una cota (o entre cotas de laderas o cimas) como principal eje o medio de asentamiento y densificación (Figura 13).
Posteriormente, en la medida que el camino de tierra se pavimenta, se observa una mayor densificación, a modo de traza tradicional (expresada en hileras de casas adyacentes al camino), fomentada por la aparición de comercio local y agrupaciones de casas con estructura de barrio tradicional, incluidos edificios, colegios, paraderos de locomoción colectiva, escalas, plazas, calles, postes y redes domiciliarias de electricidad, etc. La consolidación urbana de los barrios finalmente se percibe ya con claridad en el empalme al sector más tradicional del barrio O’Higgins, que llega hasta la Avenida Argentina. Por cierto, en este recorrido es frecuente ver bolsones verdes, no pertenecientes a antejardines o patios particulares, o sitios eriazos, que constituyen piezas adyacentes a quebradas, que en su mayoría ya están rodeados por piezas urbanas de diferente e irregular tamaño, y que bien pudieran describirse en términos de lo que algunos autores denominan "periferias interiores" (ver Kapstein, 2010; Cañete y Vargas, 2017), dado no solo por la falta de urbanización o densificación, como en el caso de los usualmente denominados intersticios, caracterizados por la descomposición del tejido urbano, sino que en este caso lo que lo caracteriza es que son bolsones que aún no han sido domesticados, por así decirlo, como parte

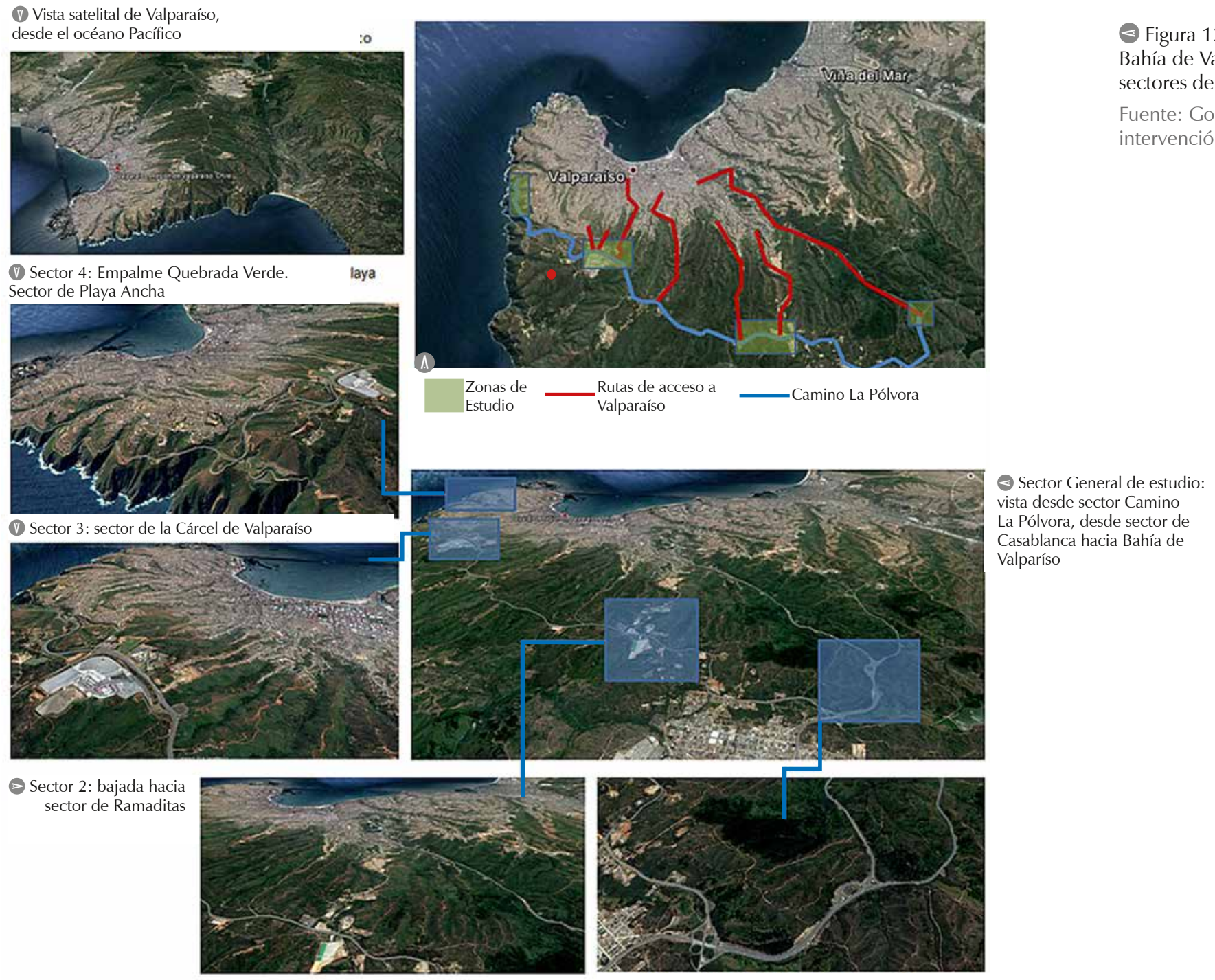

(4) Sector 1: inicio del camino La Pólvora-Empalme ruta 68 y camino a sector de Casablanca. 

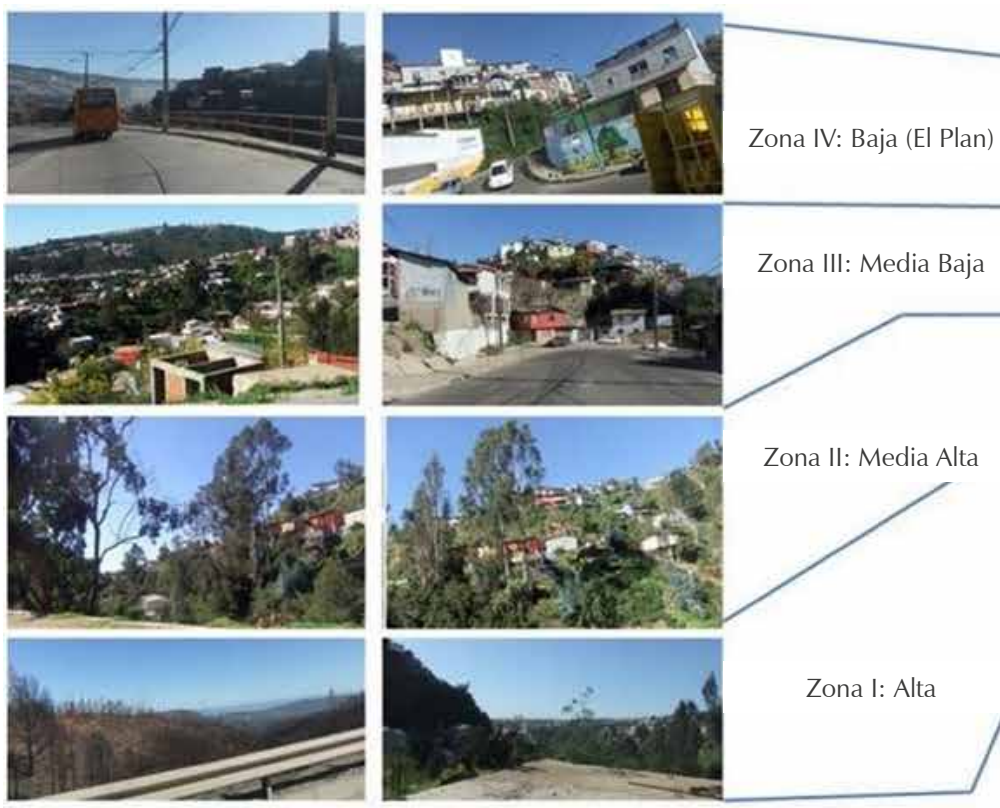

Bajada San Roque
BARRIO O'HIGGINS AVENIDA ARGENTINA

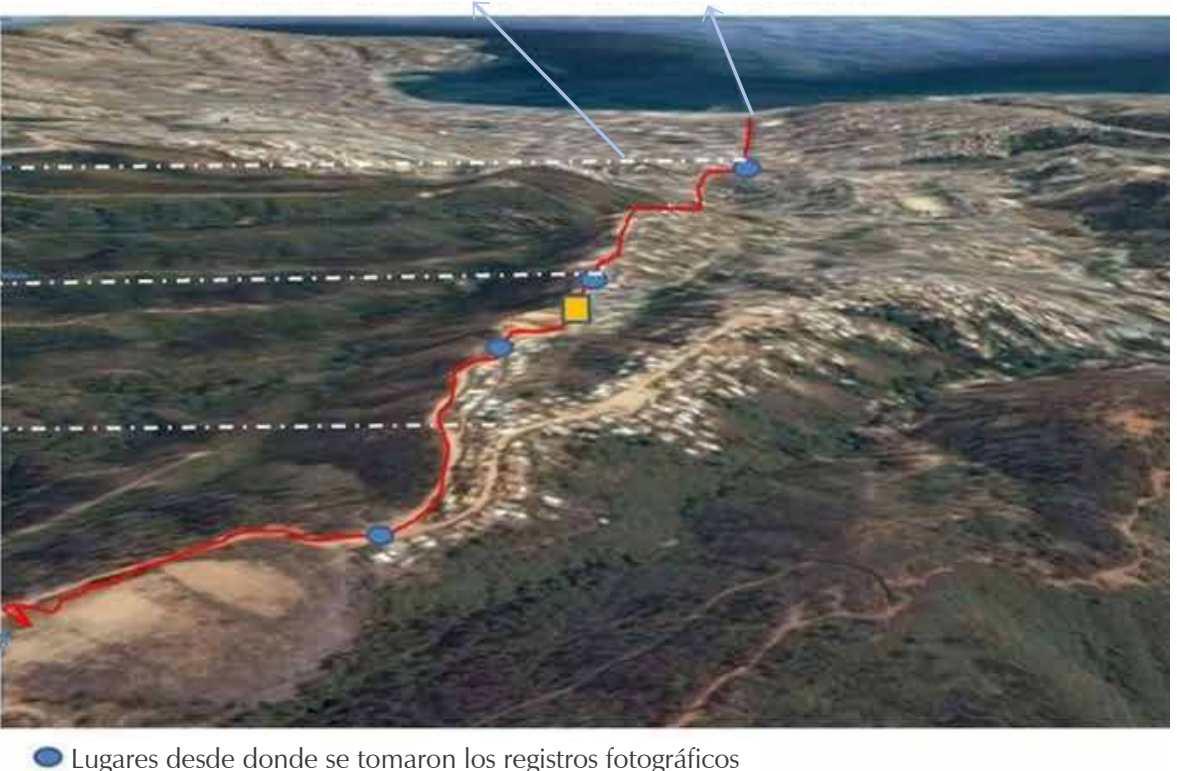

- Lugares desde donde se tomaron los registros fotográficos

$\square$ Inicio camino pavimentado hacia abajo

(A) Figura 18. Zonificación según gradiente de habitabilidad desde el plan hacia la cima, desde la bajada San Roque hacia su empalme en la Avenida Argentina Fuente: Google earth.

Debe señalarse que en el incendio de mayo de 2014, las principales oleadas de viento que arrastraron el fuego se produjeron en la zona aledaña ubicada en la quebrada de Las Cañas, colindante al cerro Ramaditas y la quebrada de Rocuant, sector del presente estudio. De hecho, ambas confluyen en la Avenida Argentina por el sector de Santa Helena, siendo parte de un sistema de quebradas mayor.

Como se aprecia en las fotos (Figuras 15 a 17), en la medida que se encuentran asentamientos en las zonas más altas, estos corresponden a sistema multifamiliares, que viven rodeados de vegetación, en verdaderos sistemas rur-urbanos de vida. Luego, es posible ver procesos de autoconstrucción que empiezan a ocupar las laderas de las quebradas, dejando diversos bolsones de mayor o menor extensión. Hacia abajo, en dirección al plan, se han identificado las siguientes zonas de habitabilidad, que en conjunto conforman una verdadera gradiente:

\section{Zona I: sector alto}

Bajamente densificados, agrupaciones multifamiliares rodeadas de árboles, porciones de bosques, arbustos y matorrales (Figura 15).

\section{Zona 2: sector alto medio}

Consolidación de trazas siguiendo la línea de cima. Aparecen agrupaciones que consolidan asentamientos en las laderas, mientras el fondo de quebrada no ha sido urbanizado, y suele ser una suerte de franja de porciones de bosques, matorrales y arbustos (Figura 16).

Zona 3: sector medio bajo con sistemas urbanizados

Se caracteriza por aparecer ya la vegetación con menor intensidad, como bolsones entre casas,

\section{Generación de capas y layers}

Velocidad de los vientos.

Incidencia del calor y radiación solar.

Cotas y alturas geomorfológicas (sistemas de cimas y quebradas)

Sistema de caminos y huellas.

Sistemas de mayor densificación local.

Sistema de áreas verdes (especies introducidas y especies nativas).

Identificación de zonas habitables más sombrías y solanas.

con laderas más densificadas y calles principales con veredas y escalas (Figura 17).

Lo anterior puede verse como un continuo de densificaciones en el recorrido visual en terreno (Figura 18).

Por su parte, las variables geomorfológicas consideradas se observan en la Tabla 1.

El desarrollo de estas variables geomorfológicas permitió la elaboración de los gráficos con los cuales se realiza la caracterización y el análisis del sector de estudio (Figuras 19 a 23).

\section{Comentarios y reflexiones finales}

\section{Implicancias desde el punto de vista de modelos de intervención y políticas sociales}

Desde el punto de vista general parece pertinente la consolidación de modelos integrados que consideren variables morfológico-territoriales y de densificación urbana como marca general
(A) Tabla 1. Variables geomorfológicas Fuente: elaboración propia, 2017. 

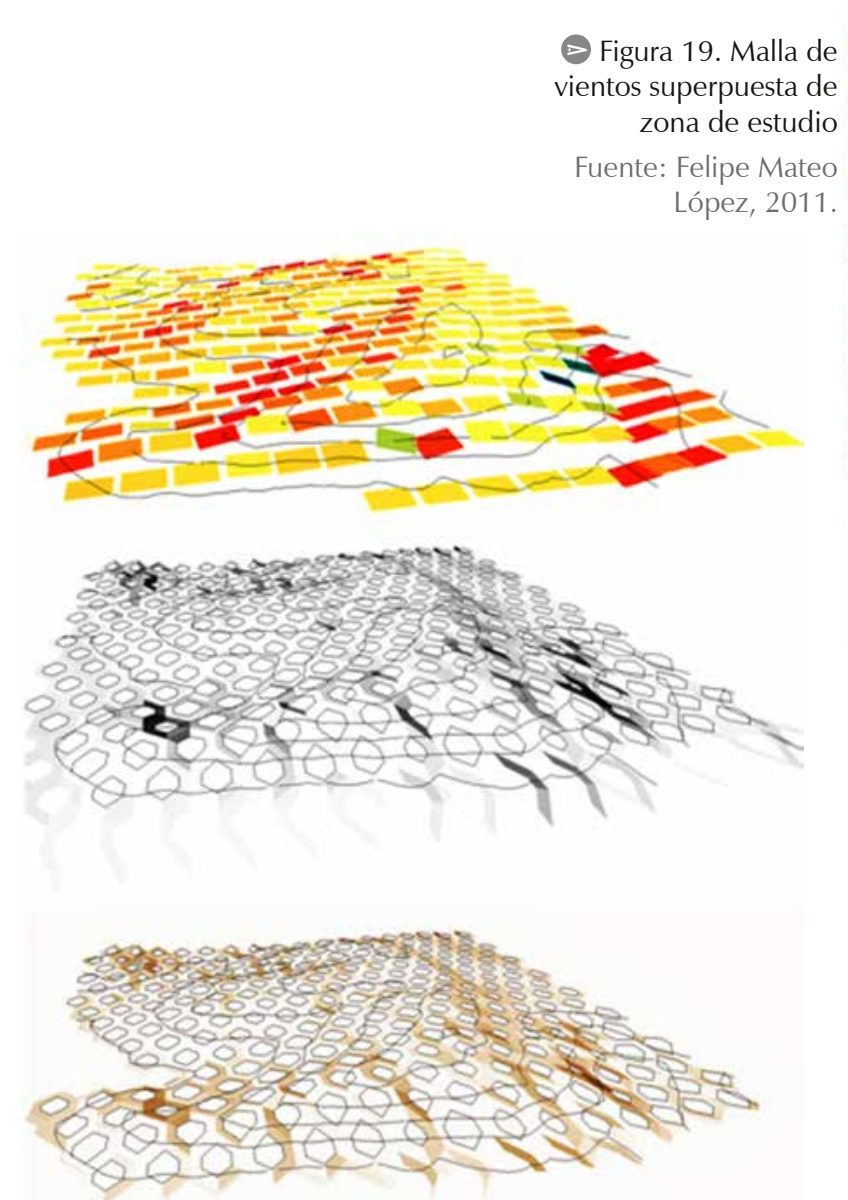

(4) Figura 20. Mapa de soleamiento de la bahía. Los sectores más rojos indican mayor intensidad

Fuente: Lopez, (2011)

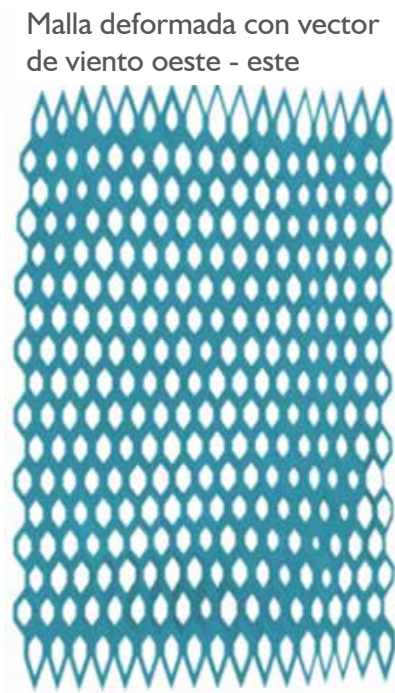

Superposición de mallas Malla 3D zona afectada

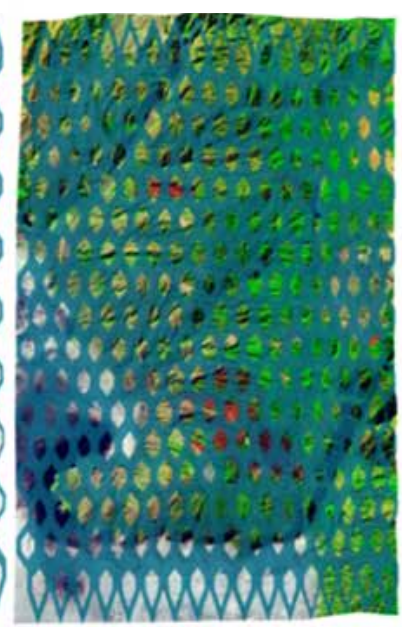

Propuesta lámina I:2000 Zona afectada
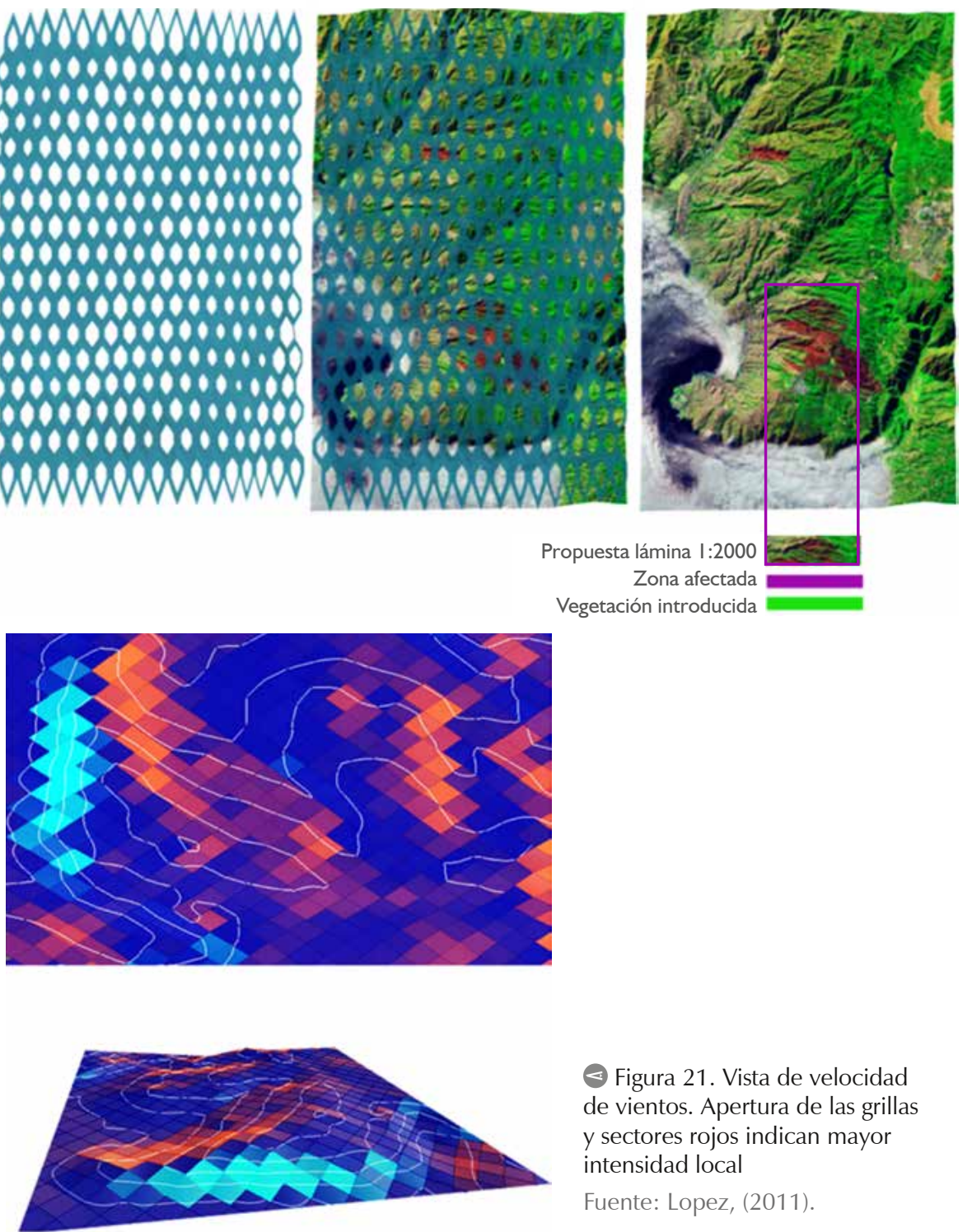

8igura 21. Vista de velocidad de vientos. Apertura de las grillas y sectores rojos indican mayor intensidad local

Fuente: Lopez, (2011).
(Moraga, Cañete y López, 2011; 2013), resumidos en el siguiente modelo genérico.

Un carácter específico de este modelo-marco es la posibilidad de generar zonificaciones territoriales con mayor validez local. Esto supone un análisis, no solo de la superposición de diversas capas de variables, como se ha realizado en el presente estudio, sino avanzar en una comprensión a escala de dicha interacción, proponiendo una zonificación a escala humana.

Por otro lado, implica cuestionarnos acerca de las políticas sociales. Esto debería ser asimilado desde el punto de vista del desarrollo de políticas sociales, especialmente de agencias estatales como el Ministerio de Vivienda y Urbanismo (Minvu), que considera en sus modelos solo variables sociourbanas principalmente, por lo que existe una brecha general respecto del territorio.

También debe considerarse plantear el debate de qué tipo de ciudad queremos, más aún con posterioridad al incendio de abril de 2014, y dada la toma de decisiones concentradas en el Gobierno central como la designación de personeros y equipos profesionales destinados a la reconstrucción y el mejoramiento de las políticas locales, con la consecuente destinación de importante gasto público. Para esto parece pertinente reflexionar sobre las preguntas que planteara el destacado investigador Edwin Haramoto (2002), quien identifica las siguientes situaciones generales, sobre las cuales se han de tomar decisiones acerca de las transformaciones y consecuentes políticas sociales relativas al crecimiento, la densificación y la urbanización de la ciudad o parte de ella:

- Una ciudad que se reconstruye a partir de la destrucción de una porción de ella. Básicamente en el mismo lugar afectado.

- Una ciudad que se construye y orienta su crecimiento hacia su periferia.

- Una ciudad que se distiende de su centro histórico, básicamente asociado al desarrollo de nuevos centros urbanos y cívicos.

En el presente caso, parte del debate debería canalizarse respecto a las zonas siniestradas, en términos de qué se busca lograr con una intervención. Es claro que una mera reconstrucción en los mismos lugares, sin tomar medidas específicas, es exponerse a los mismos factores de riesgo y, por ende, a nuevos desastres, pero por otro lado debe reconocerse al fuerte arraigo como una dimensión relevante. En esta línea, deberían tenerse en 

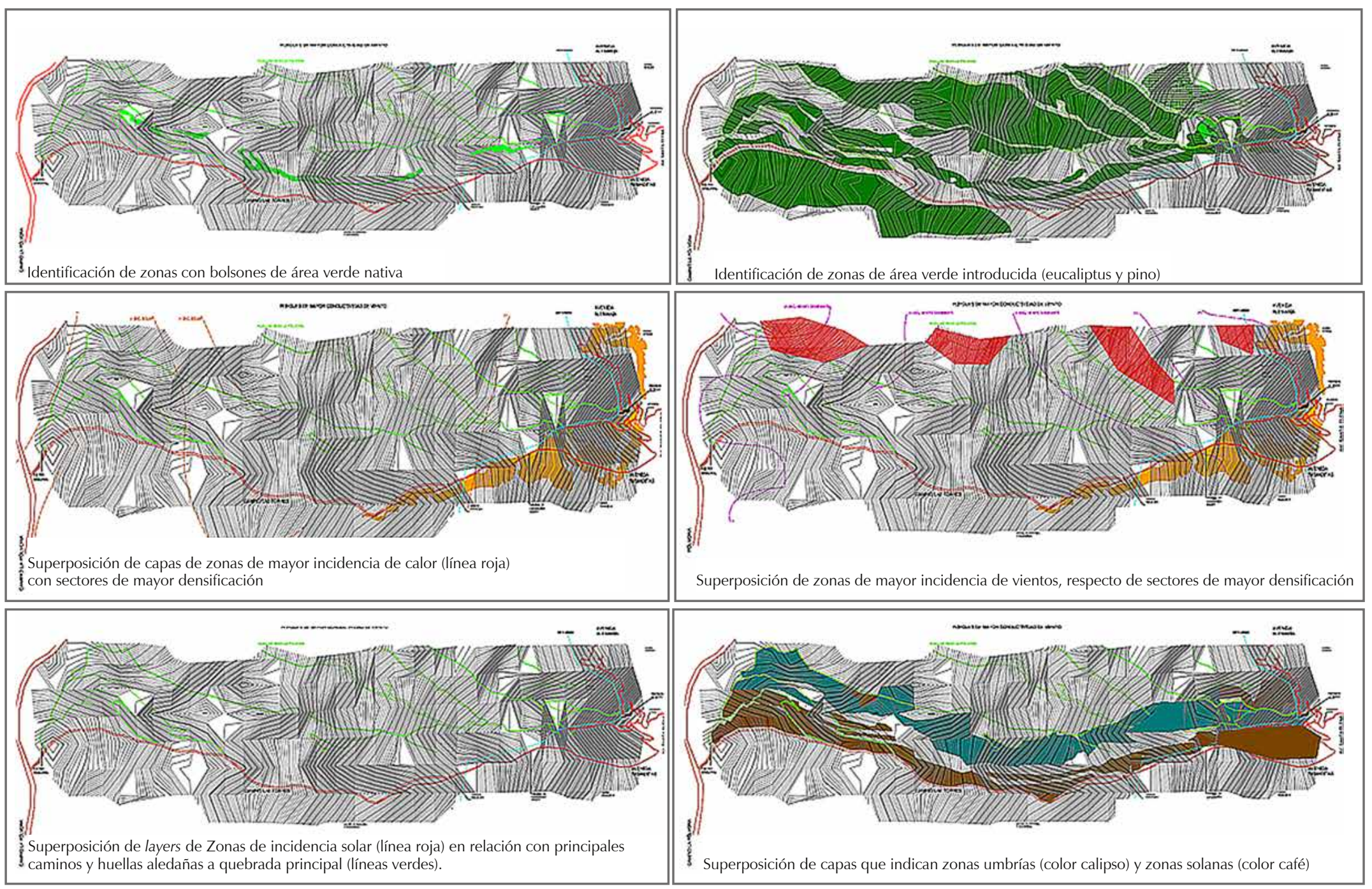

(A) Figura 22. Mapa superpuesto que indica, mediante layers, diversas variables morfoterritoriales del sector en estudio

Fuente: elaboración propia.
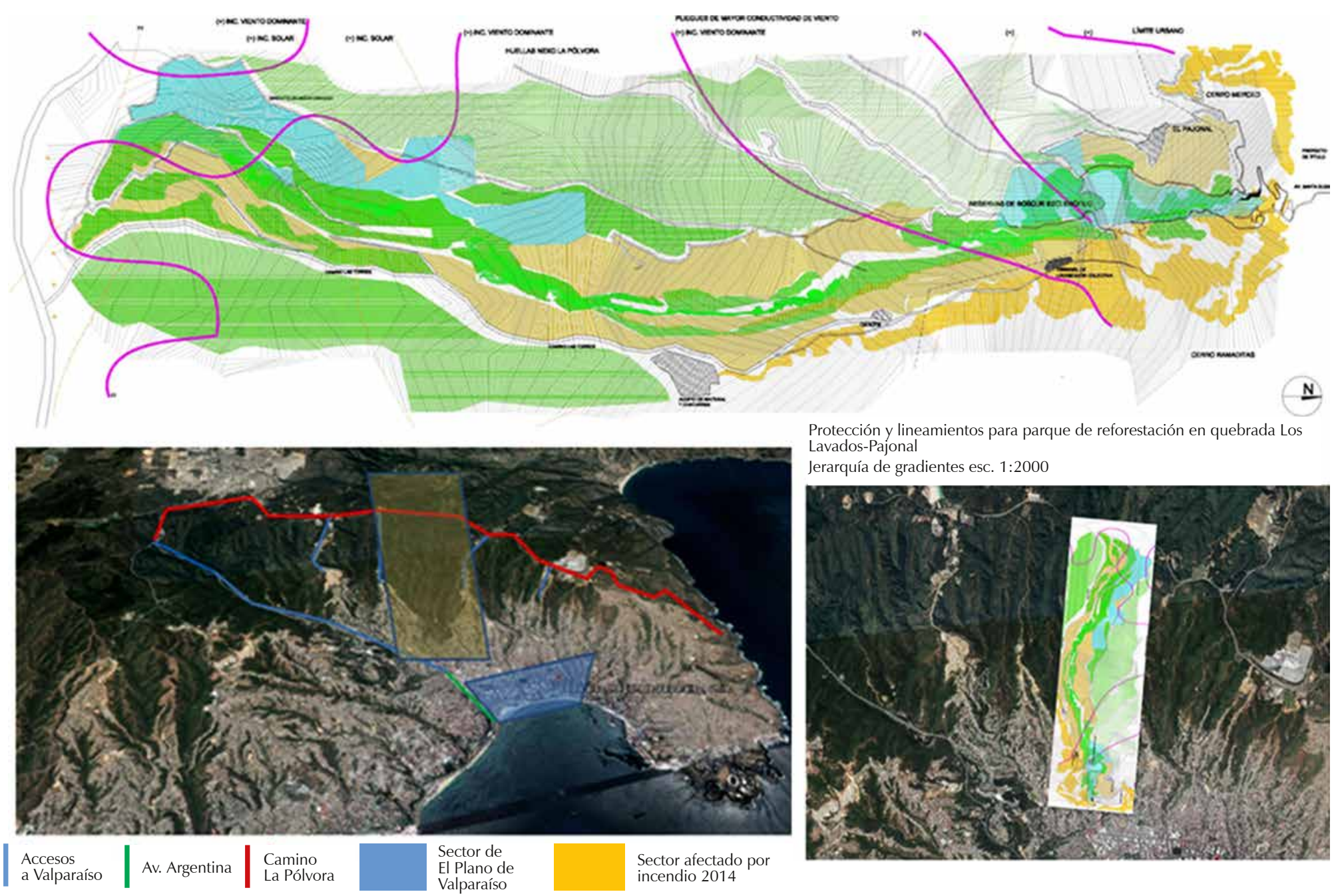

Protección y lineamientos para parque de reforestación en quebrada Los Lavados-Pajonal Jerarquía de gradientes esc. 1:2000

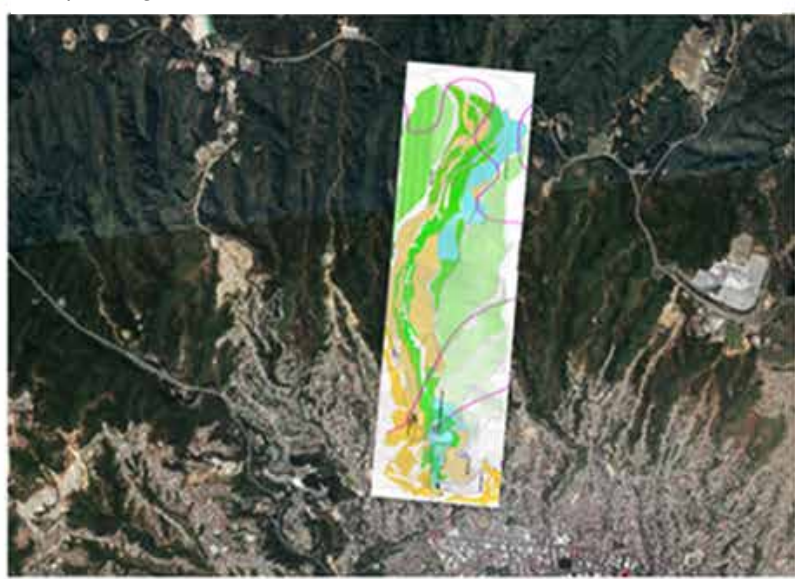

(A) Figura 23. Mapa superpuesto con layers que indican la velocidad y dirección de los vientos dentro de los sistemas de quebradas-cimas, zonas boscosas y densificadas, junto a la zonificación de gradiente territorial, propuesta por autores

Fuente: elaboración propia. 
cuenta la delimitación de zonas de reconstrucción, la delimitación clara de la traza urbana específica para cada caso y quebrada, los niveles de urbanización básica, la construcción de accesos, las bajadas de agua, la formación de taludes, de muros de contención, el acceso de grifos, etc.

En el segundo escenario, claramente debe plantearse cómo regular el crecimiento espontáneo hacia la periferia externa del borde superior, tal cual se ha dado hasta ahora. De hecho, parte de la crítica actual a los procesos de autoconstrucción, e incluso al rol del voluntariado y del Gobierno local en la reconstrucción de los sectores siniestrados apunta a este tipo de opción desde el punto de vista de una política social.

En el caso de la tercera situación, claramente implica concebir la planificación de centros cívicos y urbanos en las mesetas superiores, donde actualmente existen aún un sinnúmero de bosques y predios particulares o de bienes nacionales que deberían ser habilitados para su urbanización, creando una nueva ciudad en el borde superior donde reubicar parte de la población remanente, que actualmente no ha sido capaz de ser absorbida por el tejido social y urbano del casco histórico o vernacular consolidado. Debe recordarse que esta opción ya fue llevada a cabo en la década de los sesenta en la ciudad de Viña del Mar, en la denominada población de Gómez Carreño, lo que ha constituido una de las experiencias de intervención a gran escala más duraderas y exitosas en este sentido en la quinta región, y propuesta académicamente por Oyarzún et al. (1998). De hecho, puede pensarse que la disminución de población de Valparaíso, en favor del emergente sector de Curauma, en la ruta 68, es un indicio de este tipo de poblamiento alterno. Así sea por una acción tomada racional o espontáneamente, se dará alguna forma de repoblación y consecuente densificación en estos sectores. En consecuencia, la pregunta es qué tipo de intervenciones mitigadoras y de urbanización han de tomarse en los lugares afectados.

Por último, en próximos artículos se espera abordar cada uno de los restantes sectores identificados en el camino La Pólvora, por su relevancia respecto a ubicarse en sectores de mayor contacto, crecimiento y densificación, o por el potencial morfológico-territorial de sus trazas.

\section{Modelos morfológico-dinámicos en la densificación urbana vernacular con base en gradientes de habitabilidad}

A partir de lo expuesto hemos definido una relación fluida y dinámica en la formación de tejido urbano, de dos procesos aparentemente opuestos: a) por un lado, la generación de límites y periferias, tanto exteriores (Cañete, Lacoste, López, 2015, 2016) como interiores (Vargas, 2016; Cañete y Vargas, en elaboración, 2017), asociados al crecimiento vernáculo observado en Valparaíso, y la consecuente generación de criterios de zonificación que reconozcan esta complejidad; b) por otro, se destacan los propios procesos de asentamiento y densificación urbana que usualmente pueden ser descritos según los modelos de Lenguaje de Patrones (Alexander; $1979,1985,2005)$ y de red urbana de Salingaros (2005), y, complementariamente, a partir de los criterios definidos por Waisberg (1995), de formación de la traza en Valparaíso. La confluencia de ambos principios nos permite comprender mejor la propuesta y el alcance de la noción de gradiente de habitabilidad propuesta por los autores, lo que puede se resume en la Figura 24.

\section{Gradientes de habitabilidad y necesidad de regulación e intervención en zonas de riesgo}

Un estudio de este tipo, que identifica gradientes de habitabilidad en función del territorio, también nos permite acercarnos a la comprensión e identificación de zonas de mayor riesgo, las que en nuestro caso, dadas por las condiciones geomorfológicas del sector, nos hablan de que los incendios en época estival suelen propagarse desde la meseta superior hacia el plano medio principalmente, según nuestras zonas de gradiente I y II identificadas, dada la mixtura entre sitios no urbanizados, pero con alta densificación vernacular, que además cuentan con alta presencia de árboles, arbustos y matorrales, a lo que se agrega el deterioro del fondo de quebrada por su uso como basurero, lo que combinado con el viento que suele bajar por las quebradas, es un agente en la propagación del fuego (Figuras 25 y 26). $\gg$ Figura 24. Modelo dinámico general en la formación de límites urbanos

Fuente: Cañete y Vargas, 2017.

Habitar y densificación urbana espontánea vernacular

(Alexander, 2005)

$\begin{aligned} & \text { Densificación en límites } \\ & \text { exteriores }\end{aligned}$
(Oyarzún y Galdames,
1998; Cañete, Lacoste y
López, 2011, 2013)
Generación de
intersticios y periferias
interiores
(Kapstein, 2010; Vargas,
2016)

Morfologías irregulares
en zonas de transición
interna-externa
(Vargas, 2016)

Generación de trazas y tejido urbano en Valparaíso

(Waisberg, 1979) 


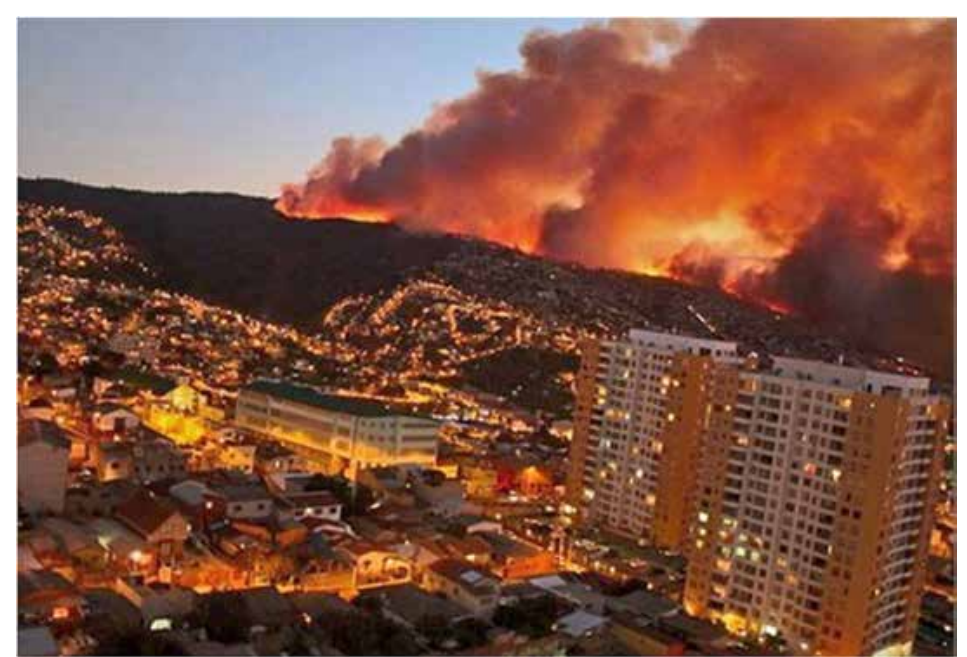

(A) Figura 25. Imagen del incendio de la zona en 2014 Fuente: El territorio (2014, abril 14).

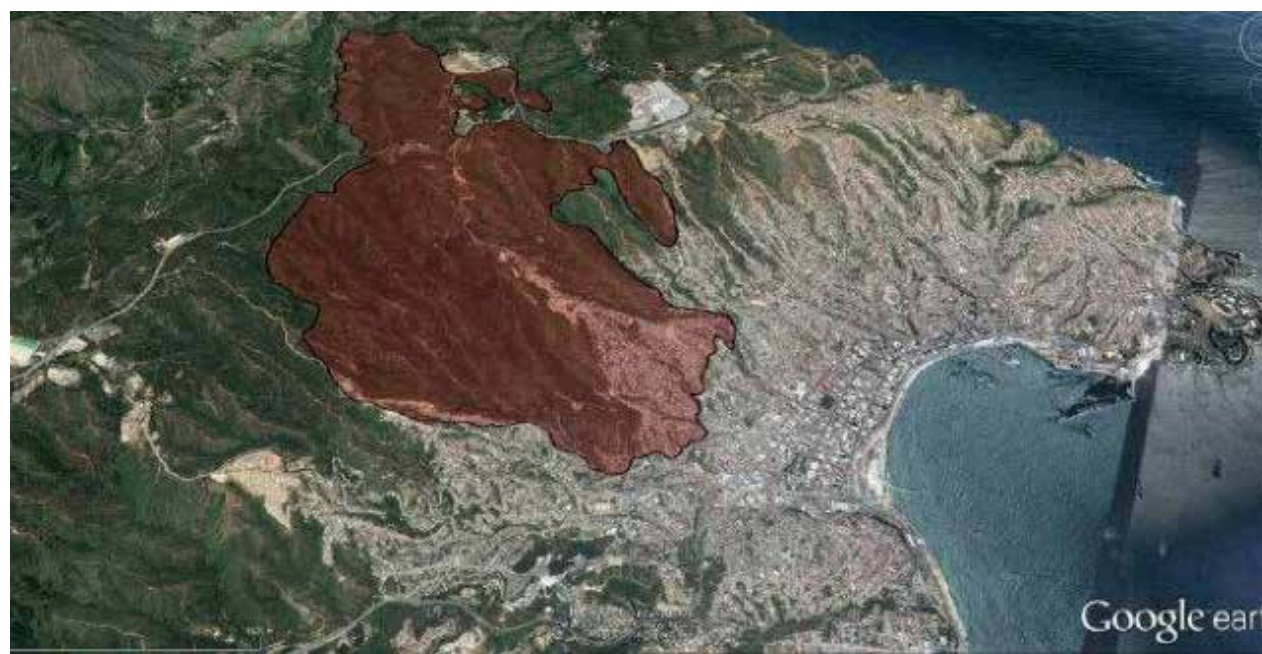

(A) Figura 26. Vista aérea desde la bahía hasta la meseta superior, donde se aprecia el camino La Pólvora. En el sector destacado en rojo se muestra el territorio abarcado por el incendio de abril de 2014

Fuente: elaboración propia a partir de Google Earth, 2017.

\section{Referencias}

Alexander, C. y Schmidt, R. (2005a). The generative master Plan. For The New Town Of harbor hills. Berkeley: Center for Environmental Structure.

Alexander, C. (2002). The Nature of Order. Berkeley: Center for Environmental Structure.

Alexander, C., Ishikawa, S. y Silverstein M. (1977). Un lenguaje de patrones. Barcelona: Gustavo Gili.

Alexander, C. (2004a). A part of the generative code. The Path to Building Welcoming, Beautiful, Sustainable Neighborhoods. [Documento en revisión V. 17]. Recuperado de http://www.livingneighborhoods.org/library/ generativecodesv10.pdf

Alexander, C. (2004b). Sustainability and Morphogenesis. The Birth of a Living World. Berkeley: Center for Environmental Structure.

Alexander, C. (2005b). Creating generative code for a new neighborhood of houses in strood (unfinished working draft version 12). Berkeley: Center for Environmental Structure. Recuperado de http://www.livingneighborhoods.org/library/stroodcode-v13.pdf

Alexander, C. (2005d). Unfolding of a Community from a Generative Code. The Riverside Community of Strood. Centre for Evironmental Structure - Europe. Recuperado de http://www.livingneighborhoods.org/library/ stroodunfolding-v19.pdf

Alexander, C. (2006). The Heart of the City. A Necessary Binding Force that Creates the Core of Every City. Berkeley: Center for Environmental Structure. Recuperado de https:// vdocuments.com.br/the-heart-of-the-cityv18.html

Alexander, C. (2007). Harmony-Seeking Computations: A Science of Non-Classical Dynamics based on the Progressive Evolution of the Larger Whole. Berkeley: Universidad de California. Recuperado de http://www. livingneighborhoods.org/library/harmonyseeking-computations.pdf

Alexander, C., Schmidt, R., Hanson, B., Alexander, M. M. y Mehaffy, M. (2005). Generative Codes. The Path to Building Welcoming, Beautiful, Sustainable Neighborhoods. Recuperado de http://www.livingneighborhoods. org/ht-0/archive.htm

Alexander, C., Solomon, D., Anninou, A., Clarke, K. y Wall, P. (1987). City of Pasadena Zoning Code. Berkeley: Center for Environmental Structure.
Cañete Islas, O. (2017a). Complejidad, forma y arquitectura. Madrid: Académica Española.

Cañete Islas, O. (2017b). Habitar en la quebrada. Resiliencia urbana y lenguaje de patrones en Valparaíso, Chile. Revista de Urbanismo, (37), 1-19. Doi: https://doi.org/10.5354/07175051.2017.47987

Cañete Islas, O. y Vargas, M. (2017). Transiciones morfológicas entre periferias exteriores e interiores en la formación de tejido y densificación urbana espontánea en Valparaíso. Documento de trabajo.

El Territorio (2014, abril 14). Al menos once muertos por el peor incendio de la historia en Valparaíso. El Territorio. [Fotografía]. Recuperado de http://www.elterritorio. com.ar/verimg.aspx? $\mathrm{F}=1 \& \mathrm{~A}=788 \& \mathrm{O}=1$ img/1/154/3836607350669328_1.jpg

Haramoto Nishikimoto, E. (2002). Un sistema de información en vivienda. Una proposición preliminar. Revista INVI, 16(44), 33-47. Recuperado de http://www.revistainvi.uchile.cl/index.php/INVI/article/view/405/996

Kapstein, P. (2010). Vulnerabilidad y periferia interior. Urban, Cuadernos de investigación urbanística, (71), pp. 30-43.

López, F. M. (2011). Huella arquitectónica. Aproximaciones a la morfología natural, patrones generativos y autoorganizados y sus influencias en la toma de decisión proyectual, de orden y organización arquitectónica. Universidad de Valparaíso: Seminario de título, Escuela de Arquitectura.

MINVU (2011). Síntesis del coloquio regional "Barrios, ciudad y democracia". Recuperado de https:/www.ead.pucv.cl/app/ uploads/2012/02/Sintesis-Ciclo-de-Coloquios-1.pdf

Moraga, J., Cañete Islas, O. y López, M. (2011). Geomorfología del lugar, huellas y patrones ambientales como factor cohesionador de Proyectos e Intervenciones de barrios. Coloquio realizado por MINVU regional sobre Políticas de Recuperación Barrial e Identidad Local. Recuperado de http://www.livestream.com/ recuperaciondebarrios/video? clipld $=$ pla caa4c913-e43a-4d3c-90c3-9ceab8740ed5

Moraga, J. L., Cañete, O. y López, F. (2013). Modelos de densificación según gradientes territoriales de habitabilidad en la conurbación interior Valparaíso-Viña del Mar. Revista de Arquitectura, 15(1), 22-32. Doi: https://doi. org/10.14718/revarq.2013.15.1.3
Oyarzún, A., Arancibia, R. y Galdames, L. et al. (2006). Estudio sobre el borde superior de Valparaíso. Presentación. Escuela de Arquitectura, Universidad de Valparaíso. XIX Congreso de la Unión Internacional de Arquitectos, Barcelona.

Oyarzún, A., Arancibia, R., Galdames, L. et al. (1995). Estudio sobre el borde superior de Valparaíso. Revista Facultad de Arquitectura, Monografía especial, 2 (2). Recuperado de https://es.calameo.com/read/00038572328347aa2818a

Pino, A. (2014). Quebradas de Valparaíso. Memoria social autoconstruida. Santiago de Chile: Consejo Nacional de Artes y Culturas, Cigiden, Universidad Técnica Francisco Santa María. Recuperado de https://www. researchgate.net/publication/282328448 Quebradas_de_Valparaiso_Memoria_ social_autoconstruida

Salingaros, N. (1999). El espacio urbano y su campo de información. Revista de diseño urbano, 4, 29-49.

Salingaros, N. (2000). The structure of pattern languages. Architectural Research Quarterly, 4(2), 149-162. Doi: https://doi.org/10.1017/ S1359135500002591

Salingaros, N. (2004). Conectando la ciudad fractal. En Principles of Urban Structure. Amsterdam: Techne Press, Amsterdam. Recuperado de http://zeta.math.utsa.edu/ yxk833/fractalcity-spanish.pdf

Salingaros, N. (2005). Complejidad y coherencia urbana. Revista de diseño urbano, 5, 291316.

Salingaros, N. (2007). Redes: una aproximación al fenómeno urbano. Cuadernos de arquitectura y nuevo urbanismo, 3, 5-18. Recuperado de https://repositorio.itesm.mx/ handle/11285/573456

Salingaros, N. (2008). La estructura de los lenguajes de patrones. Cuadernos de arquitectura y nuevo urbanismo, 5 (3), 25-48. Recuperado de http://hdl.handle.net/11285/573460

Waisberg, M. (1979). La traza urbana. Patrimonio consolidado de Valparaíso. Buenos Aires: Centro Internacional para la Conservación del Patrimonio. 


\section{Enfoque y alcance}

La Revista de Arquitectura (Bogotá) (ISSN 1657-0308 Impresa y E-ISSN 2357-626X en línea) es una publicación seriada de acceso abierto, arbitrada mediante revisión por pares (doble ciego) e indexada, en donde se publican resultados de investigación originales e inéditos.

Está dirigida a la comunidad académica y profesional de las áreas afines a la disciplina. Es editada por la Facultad de Diseño y el Centro de Investigaciones (CIFAR) de la Universidad Católica de Colombia en Bogotá (Colombia).

La principal área científica a la que se adscribe la Revista de Arquitectura (Bogotá) según la OCDE es:

Gran área: 6. Humanidades

Área: 6.D. Arte

Disciplina: 6D07. Arquitectura y Urbanismo

También se publican artículos de las disciplinas como 2A02, Ingeniería arquitectónica; 5G03, Estudios urbanos (planificación y desarrollo); 6D07, Diseño.

Los objetivos de la Revista de Arquitectura (Bogotá) son:

- Promover la divulgación y difusión del conocimiento generado a nivel local, nacional e internacional

- Conformar un espacio para la construcción de comunidades académicas y la discusión en torno a las secciones definidas.

- Fomentar la diversidad institucional y geográfica de los autores que participan en la publicación.

- Potenciar la discusión de experiencias e intercambios científicos entre investigadores y profesionales.

- Contribuir a la visión integral de la arquitectura, por medio de la concurrencia y articulación de las secciones mediante la publicación de artículos de calidad.

- Publicar artículos originales e inéditos que han pasado por revisión de pares, para asegurar que se cumplen las normas éticas, de calidad, validez científica, editorial e investigativa.

- Fomentar la divulgación de las investigaciones y actividades desarrolladas en la Universidad Católica de Colombia.
Palabras clave de la Revista de Arquitectura (Bogotá): arquitectura, diseño, educación arquitectónica, proyecto y construcción, urbanismo.

Idiomas de publicación: español, inglés, portugués y francés.

Título abreviado: Rev. Arquit.

Titulo corto: RevArq

\section{Políticas de sección}

La revista se estructura en tres secciones correspondientes a las líneas de investigación activas y aprobadas por la institución, y dos complementarias, que presentan dinámicas propias de la Facultad de Diseño y las publicaciones relacionadas con la disciplina.

Cultura y espacio urbano. En esta sección se publican los artículos que se refieren a fenómenos sociales en relación con el espacio urbano, atendiendo aspectos de la historia, el patrimonio cultural y físico, y la estructura formal de las ciudades y el territorio.

Proyecto arquitectónico y urbano. En esta sección se presentan artículos sobre el concepto de proyecto, entendido como elemento que define y orienta las condiciones proyectuales que devienen en los hechos arquitectónicos o urbanos, y la forma como estos se convierten en un proceso de investigación y nuevo de conocimiento. También se presentan proyectos que sean resultados de investigación, los cuales se validan por medio de la ejecución y transformación en obra construida del proceso investigativo. También se contempla la publicación de investigaciones relacionadas con la pedagogía y didáctica de la arquitectura, el urbanismo y el diseño.

Tecnología, medioambiente y sostenibilidad. En esta sección se presentan artículos acerca de sistemas estructurales, materiales y procesos constructivos, medioambiente y gestión, relacionados con los entornos social-cultural, ecológico y económico.

Desde la Facultad. En esta sección se publican artículos generados en la Facultad de Diseño, relacionados con las actividades de docencia, extensión, formación en investigación o internacionalización, las cuales son reflejo de la dinámica y de las actividades realizadas por docentes, estudiantes y egresados; esta sección no puede superar el $20 \%$ del contenido.

Textos. En esta sección se publican reseñas, traducciones y memorias de eventos relacionados con las publicaciones en Arquitectura y Urbanismo.

\section{A Frecuencia de publicación}

Desde 1999 y hasta el 2015, la Revista de Arquitectura (Bogotá) publicó un volumen al año, a partir del 2016 se publicarán dos números por año en periodo anticipado, enero-junio y julio-diciembre, pero también maneja la publicación anticipada en línea de los artículos aceptados (versión Post-print del autor).

La Revista de Arquitectura (Bogotá) se divulga mediante versiones digitales (PDF, HTML, EPUB, XML) e impresas con un tiraje de 700 ejemplares, los tiempos de

Universidad Católica de Colombia (2018,
julio-diciembre).
Revista de Arquitectura (Bogotá),
20(2), I-I28. Doi: I0.I47/8
ISSN: 1657-0308
E-ISSN: 2357-626X
Especificaciones:
Formato: 34 x $24 \mathrm{~cm}$
Papel: Mate II5 g
Tintas: Negro y policromía

producción de estas versiones dependerán de los cronogramas establecidos por la editorial.

Los tiempos de recepción-revisión-aceptación pueden tardar entre seis y doce meses dependiendo del flujo editorial de cada sección y del proceso de revisión y edición adelantado.

Con el usuario y contraseña asignados, los autores pueden ingresar a la plataforma de gestión editorial y verificar el estado de revisión, edición o publicación del artículo.
A Canje

La Revista de Arquitectura está interesada en establecer canje con publicaciones académicas, profesionales o científicas del área de Arquitectura y Urbanismo, como medio de reconocimiento y discusión de la producción científica en el campo de acción de la publicación.

\section{Mecanismo}

Para establecer canje por favor descargar, diligenciar y enviar el formato: RevArq FP20 Canjes 
Universidad Católica de Colombia

Presidente

Édgar Gómez Betancourt

Vicepresidente - Rector

Francisco José Gómez Ortiz

Vicerrector Jurídico

Edwin de Jesús Horta Vásquez

Vicerrector Administrativo

Édgar Gómez Ortiz

Vicerrector Académico

Elvers Medellín Lozano

Director de Investigaciones

Edwin Daniel Durán Gaviria

Directora Editorial

Stella Valbuena García

\section{Facultad de Diseño}

Decano

Werner Gómez Benítez

Director de docencia

Jorge Gutiérrez Martínez

Directora de extensión

Adriana Pedraza Pacheco

Director de investigación

Hernando Verdugo Reyes

Director de gestión de calidad

Augusto Forero La Rotta

Comité asesor externo

Facultad de Diseño

Édgar Camacho Camacho

Martha Luz Salcedo Barrera

Samuel Ricardo Vélez
Facultad de Diseño

Centro de Investigaciones - CIFAR
Revista de acceso abierto

arbitrada e indexada

Publindex: Categoría B. Índice Bibliografico Nacional IBN.

Esci: Emerging Source Citation Index.

Doaj: Directory of Open Access Journals.

Redalyc: Red de Revistas Cientificas de América Latina y el Caribe, España y Portugal.

SciELO: Scientific Electronic Library Online - Colombia

Redib: Red Iberoamericana de Innovación y Conocimiento Cientifico.

Ebsco: EBSCOhost Research Databases.

Clase: Base de datos bibliográfica de revistas de ciencias sociales y

humanidades.

Latindex: Sistema Regional de Información en Línea para Revistas

Cientificas de América Latina, el Caribe, España y Portugal (Directorio

y catálogo).

Dialnet: Fundación Dialnet - Biblioteca de la Universidad de La Rioja.

LatinRev: Red Latinoamericana de Revistas Académicas en Ciencias

Sociales $y$ Humanidades.

Proquest: ProQuest Research Library.

Miar: Matrix for the Analysis of Journals.

Sapiens Research: Ranking de las mejores revistas colombianas según visibilidad internacional.

Actualidad Iberoamericana: (Índice de Revistas) Centro de Informació Tecnológica (CIT).

Google Scholar

Arla: Asociación de Revistas latinoamericanas de Arquitectura.

Editorial

Av. Caracas $N^{\circ} 46-72$, piso

Teléfono: 3277300 Ext. 5145

editorial@ucatolica.edu.co

www.ucatolica.edu.co

http://publicaciones.ucatolica.edu.co/

Impresión:

JAVEGRAF

Calle 46A No82-54 Int. 2

Bogotá, D. C., Colombia

http://www.javegraf.com.co/index.php

Agosto de 2018

\section{Revista de Arquitectura \\ (Bogotá)}

Director

Werner Gómez Benítez

Editor

César Eligio-Triana

Editores de sección

(1) Myriam Stella Díaz Osorio

(1) Carolina Rodríguez-Ahumada

(1) Anna Maria Cereghino Fedrigo

\section{Equipo editorial}

Coordinadora editorial

María Paula Godoy Casasbuenas mpgodoy@ucatolica.edu.co

Diseño y montaje

Juanita Isaza

juanaisaza@gmail.com

Traductoras

Inglés

Erika Tanacs

etanacs25@gmail.com

Portugués

Roanita Dalpiaz

roanitad@gmail.com

Correctora de estilo

María José Díaz Granados M.

mariajose_dgm@yahoo.com.co

Página Web

Centro de investigaciones (CIFAR)

Distribución y canjes

Claudia Álvarez Duquino

calvarez@ucatolica.edu.co
Comité editorial y científico

Cultura y espacio urbano

Carlos Mario Yory, PhD

Universidad Católica de Colombia. Bogotá, Colombia

Sonia Berjman, $\mathrm{PhD}$

ICOMOS-IFLA, Buenos Aires, Argentina

Juan Carlos Pérgolis, MSc Universidad Piloto de Colombia. Bogotá, Colombia

Beatriz García Moreno, PhD

Universidad Nacional de Colombia. Bogotá, Colombia

Proyecto arquitectónico y urbano

Jean-Philippe Garric, PhD, HDR

Université Paris I Panthéon-Sorbonne. Paris, Francia

Debora Domingo Calabuig, PhD

Universidad Politécnica de Valencia, España

Dania González Couret, PhD

Universidad Tecnológica de La Habana, Cuba

Hugo Mondragón López, PhD Pontificia Universidad Católica de Chile. Santiago, Chile

Juan Pablo Duque Cañas, PhD

Universidad Nacional de Colombia. Bogotá, Colombia

Tecnología, medioambiente y sostenibilidad

Mariano Vázquez Espí, PhD

Universidad Politécnica de Madrid, España

Denise Helena Silva Duarte, PhD Universidade de São Paulo (USP), Brasil

Luis Carlos Herrera Sosa, PhD Universidad Autónoma de Ciudad Juárez, México

Claudio Varini, PhD

Universidad Católica de Colombia. Bogotá, Colombia

Luis Gabriel Gómez Azpeitia, PhD Universidad de Colima. Colima, México 


\section{Contenido}

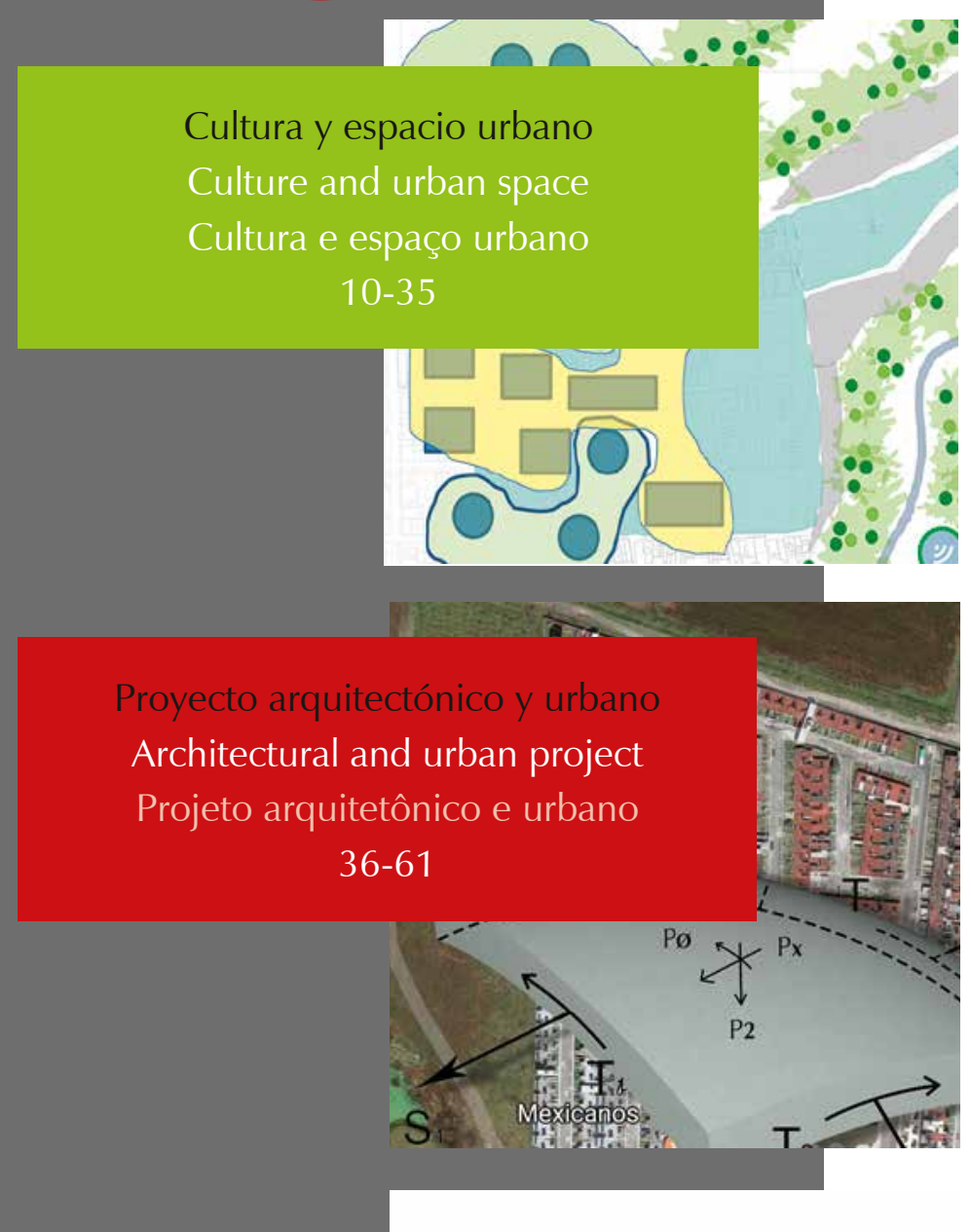

Tecnología, medioambiente

y sostenibilidad

Technology, environment and sustainability

Tecnologia, meio ambiente e sustentabilidade

62-89
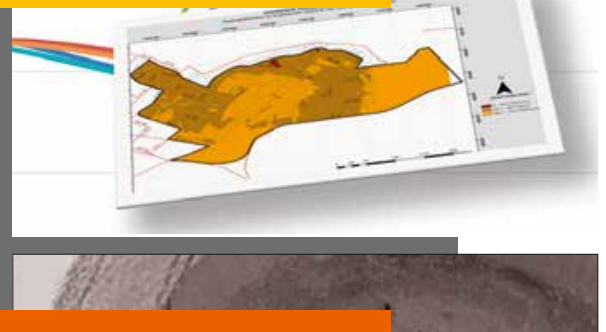

Desde la Facultad

From the Faculty

Da faculdade

90-109
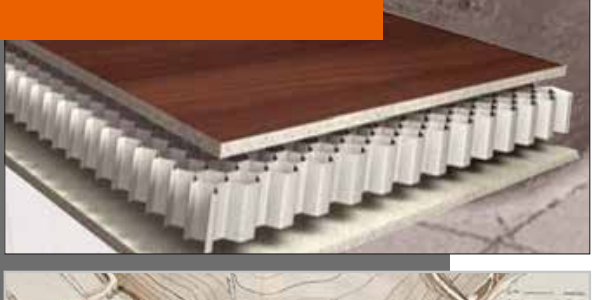

Textos

Texts

Textos

110-126

Los artículos científicos como herramienta de aprendizaje en las escuelas de arquitectura

Carolina Rodríguez-Ahumada

Pág. 3 ES

Paisaje urbano y espacio público como expresión de la vida cotidiana

Morella Briceño-Ávila

Pág. 10

\section{ES EN}

Habitar la quebrada: conformación de gradientes en las trazas vernaculares de los sectores altos de Valparaíso

\section{Omar Eduardo Cañete-Islas}

Juan Luis Moraga-Lacoste

Felipe Mateo López-Flores

Pág. 20

ES

Láminas cilíndricas en la arquitectura colombiana del siglo XX

Jorge Galindo-Díaz

Pág. 36

\section{ES EN}

Retórica simbólica en el espacio arquitectónico

Una mirada antropológica de la casa en la

sobremodernidad

Eska Elena Solano-Meneses

Pág. 51

ES

Ecoenvolventes: análisis del uso de fachadas ventiladas en clima cálido-húmedo

\footnotetext{
Sara Luciani-Mejía

Rodrigo Velasco-Gómez

Roland Hudson
}

Pág. 62

ES

Estrategias metodológicas de análisis urbano frente al cambio climático

Matriz para el diseño adaptativo en asentamientos informales

Adriana Patricia López-Valencia

Oswaldo López-Bernal

Pág. 78

ES

Muro panel térmico estructural compuesto

en guadua y cartón

Modelo experimental aplicado al clima de

la zona cafetera

Renato Cassandro-Cajiao

Pág. 90

\section{ES EN}

Continuidad y transformaciones de modelos

pedagógicos en la École Polytechnique (1867-1910)

Estelle Thibault

Traductores

Andrés Ávila-Gómez

Diana Carolina Ruiz

Pág. 110

ES 
La postulación de un artículo a la Revista de Arquitectura (Bogotá) indica que- el o los autores certifican que conocen y aceptan la política editorial, para lo cual firmarán en original y remitirán el formato RevArq FP00 Carta de originalidad.

La Revista de Arquitectura (Bogotá) maneja una política de Autoarchivo VERDE, según las directrices de SHERPA/RoMEO, por lo cual el autor puede:

- Pre-print del autor: Archivar la versión pre-print (la versión previa a la revisión por pares

- Post-print del autor: Archivar la versión post-print (la versión final posterior a la revisión por pares

- Versión de editor/PDF: Archivar la versión del editor - PDF/HTML/XLM en la maqueta de la Revista de Arquitectura (Bogotá).

El Autoarchivo se debe hacer respetando la licencia de acceso abierto, la integridad y la imagen de la Revista de Arquitectura (Bogotá), también se recomienda incluir la referencia, el vínculo electrónico y el DOI.

El autor o los autores son los titulares del Copyright (c) del texto publicado y la Editorial de la Revista de Arquitectura (Bogotá) solicita la firma de una autorización de reproducción del artículo (RevArq FP03 Autorización reproducción), la cual se acoge a la licencia CC, donde se expresa el derecho de primera publicación de la obra.

La Revista de Arquitectura (Bogotá) se guía por las normas internacionales sobre propiedad intelectual y derechos de autor, y de manera particular el artículo 58 de la Constitución Política de Colombia, la Ley 23 de 1982 y el Acuerdo 172 del 30 de septiembre de 2010 (Reglamento de propiedad intelectual de la Universidad Católica de Colombia)

Para efectos de autoría y coautoría de artículos se diferencian dos tipos: "obra en colaboración" y "obra colectiva". La primera es aquella cuya autoría corresponde a todos los participantes al ser fruto de su trabajo conjunto. En este caso, quien actúa como responsable y persona de contacto debe asegurar que quienes firman como autores han revisado y aprobado la versión final, y dan consentimiento para su divulgación. La obra colectiva es aquella en la que, aunque participan diversos colaboradores, hay un autor que toma la iniciativa la coordinación y realización de dicha obra. En estos casos, la autoría corresponderá a dicha persona (salvo pacto en contrario) y será suficiente únicamente con su autorización de divulgación.

El número de autores por artículo debe estar justificado por el tema, la complejidad y la extensión, y no deberá ser superior a la media de la disciplina, por lo cual se recomienda que no sea mayor de cinco. El orden en que se enuncien corresponderá a los aportes de cada uno a la construcción del texto, se debe evitar la autoría ficticia o regalada. Si se incluyen más personas que trabajaron en la investigación se sugiere que sea en calidad de colaboradores o como parte de los agradecimientos. La Revista de Arquitectura (Bogotá) respetará el número y el orden en que figuren en el original remitido. Si los autores consideran necesario, al final del artículo pueden incluir una breve descripción de los aportes individuales de cada uno de firmantes.

La comunicación se establece con uno de los autores, quien a su vez será el responsable de informar a los demás autores de las notificaciones emitidas por la Revista de Arquitectura (Bogotá).

En virtud de mantener el equilibro de las secciones y las mismas oportunidades para todos los participantes, un mismo autor puede postular dos o más artículos de manera simultánea; si la decisión editorial es favorable y los artículos son aceptados, su publicación se realizará en números diferentes.

\section{A Acceso abierto}

La Revista de Arquitectura (Bogotá), en su misión de divulgar la investigación y apoyar el conocimiento y la discusión en los campos de interés, proporciona acceso abierto, inmediato e irrestricto a su contenido de manera gratuita mediante la distribución de ejemplares impresos y digitales. Los interesados pueden leer, descargar, guardar, copiar y distribuir, imprimir, usar, buscar o referenciar el texto completo o parcial de los artículos o la totalidad de la Revista de Arquitectura (Bogotá).

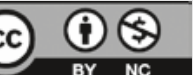

Esta revista se acoge a la licencia Creative Commons (CC BY NC de Atribución - No comercial 4.0 Internacional): "Esta licencia permite a otros entremezclar, ajustar y construir a partir de su obra con fines no comerciales, y aunque en sus nuevas creaciones deban reconocerle su autoría y no puedan ser utilizadas de manera comercial, no tienen que estar bajo una licencia con los mismos términos".

La Revista de Arquitectura es divulgada en centros y grupos de investigación, en bibliotecas y universidades, y en las principales facultades de Arquitectura mediante acceso abierto a la versión digital y suscripción anual al ejemplar impreso o por medio de canje, este último se formaliza mediante el formato RevArq FP20 Canjes

Para aumentar su visibilidad y el impacto de los artículos, se envían a bases de datos y sistemas de indexación y resumen (SIR) y, asimismo, pueden ser consultados y descargados en la página web de la revista.

La Revista de Arquitectura no maneja cobros, tarifas o tasas de publicación de artículo (Article Processing Charge-APC), o por el sometimiento de textos a la publicación.

\section{(1)Ética y buenas prácticas}

La Revista de Arquitectura se compromete a cumplir y respetar las normas éticas en todas las etapas del proceso de publicación. Los autores de los artículos publicados darán cumplimiento a los principios éticos contenidos en las diferentes declaraciones y legislaciones sobre propiedad intelectual y derechos de autor específicos del país donde se realizó la investigación. En consecuencia, los autores de los artículos postulados y aceptados para publicar, que presentan resultados de investigación, deben firmar la declaración de originalidad (formato RevArq FP00 Carta de originalidad).

La Revista de Arquitectura reconoce y adopta los principios de transparencia y buenas prácticas descritos por COPE, "Principles of Transparency and Best Practice in Scholarly Publishing" (2015).

El equipo editorial tiene la obligación de guardar la confidencialidad acerca de los artículos recibidos, y abstenerse de usar en sus propias investigaciones datos, argumentos o interpretaciones hasta tanto el artículo no sea publicado. También debe ser imparcial y gestionar los artículos de manera adecuada y en los plazos establecidos. La selección de revisores se hará con objetividad y estos deberán responder a la temática del artículo.

El editor, los autores y los revisores deben seguir las normas éticas internacionales definidas por el Committee on Publication Ethics (COPE), con el fin de evitar casos de:

- Fabricación, falsificación u omisión de datos.

- Plagio y autoplagio.

- Publicación redundante, duplicada o fragmentada.

- Omisión de referencias a las fuentes consultadas.

- Utilización de contenidos sin permiso o sin justificación.

- Apropiación individual de autoría colectiva.

- Cambios de autoría.

- Conflicto de interés (CDI) no revelado o declarado.

- Otras que pudieran surgir en el proceso de investigación y publicación. La fabricación de resultados se genera al mostrar datos inventados por los autores; la falsificación resulta cuando los datos son manipulados y cambiados a capricho de los autores; la omisión se origina cuando los autores ocultan deliberadamente un hecho o dato. El plagio se da cuando un autor presenta como ideas propias datos creados por otros. Los casos de plagio son los siguientes: copia directa de un texto sin entrecomillar o citar la fuente, modificación de algunas palabras del texto, paráfrasis y falta de agradecimientos; el autoplagio se da cuando el mismo autor reutiliza material propio que ya fue publicado, pero sin indicar la referencia al trabajo anterior. La revista se apoya en herramientas digitales que detectan cualquiera de estos casos en los artículos postulados, y es labor de los editores y revisores velar por la originalidad y fidelidad en la citación. La publicación redundante o duplicada se refiere a la copia total, parcial o alterada de un trabajo ya publicado por el mismo autor

En caso de sospechar de alguna mala conducta se recomienda seguir los diagramas de flujo elaborados por COPE (2008), con el fin de determinar las acciones correspondientes.

La Revista de Arquitectura se reserva el derecho de retractación de publicación de aquellos artículos que, posterior a su publicación, se demuestre que presentan errores de buena fe, o cometieron fraudes o malas prácticas científicas. Esta decisión se apoyará en "Retraction Guidelines" (COPE, 2009). Si el error es menor, este se podrá rectificar mediante una nota editorial de corrección o una fe de erratas. Los autores también tienen la posibilidad de solicitar la retractación de publicación cuando descubran que su trabajo presenta errores graves. En todos los casos se conservará la versión electrónica y se harán las advertencias de forma clara e inequívoca.

\section{A Privacidad y manejo de la información.} Habeas Data

Para dar cumplimiento a lo previsto en el artículo 10 del Decreto 1377 de 2013, reglamentario de la Ley 1581 de 2012, y según el Acuerdo 002 del 4 de septiembre de 2013 de la Universidad Católica de Colombia, "por el cual se aprueba el manual de políticas de tratamiento de datos personales":

La Universidad Católica de Colombia, considerada como responsable o encargada del tratamiento de datos personales, manifiesta que los datos personales de los autores, integrantes de los comités y pares revisores, se encuentran incluidos en nuestras bases de datos; por lo anterior, y en cumplimiento de las disposiciones legales vigentes, la Universidad solicitará siempre su autorización, para que en desarrollo de sus funciones propias como Institución de Educación Superior, en especial las relacionadas con la docencia, la extensión y la investigación, la Universidad Católica de Colombia pueda recolectar, recaudar, almacenar, usar, circular, suprimir, procesar, intercambiar, compilar, dar tratamiento, actualizar, transmitir o transferir a terceros países y disponer de los datos que le han suministrado y que han sido incorporados en las bases de datos de todo tipo que reposan en la Universidad.

La Universidad Católica de Colombia queda autorizada, de manera expresa e inequívoca, en los términos señalados por el Decreto 1377 de 2013, para mantener y manejar la información de nuestros colaboradores (autores, integrantes de los diferentes comités y pares revisores); así mismo, los colaboradores podrán ejercer sus derechos a conocer, actualizar, rectificar y suprimir sus datos personales, para lo cual se han dispuesto las siguientes cuentas de correo electrónico: 
La Revista de Arquitectura (Bogotá) recibe artículos de manera permanente. Los artículos se procesan a medida que se postulan, dependiendo el flujo editorial de cada sección.

El idioma principal es el español, y como opcionales están definidos el inglés, el portugués y el francés; los textos pueden ser escritos y presentados en cualquiera de estos.

Los artículos postulados deben corresponder a las categorías universalmente aceptadas como producto de investigación, ser originales e inéditos y sus contenidos responder a criterios de precisión, claridad y brevedad.

Como punto de referencia se pueden tomar las tipologías y definiciones del Índice Bibliográfico Nacional, Publindex (2010) que se describen la continuación:

1. Artículo de revisión: documento resultado de una investigación terminada donde se analizan, sistematizan e integran los resultados de investigaciones publicadas o no publicadas, sobre un campo en ciencia o tecnología, con el fin de dar cuenta de los avances y las tendencias de desarrollo. Se caracteriza por presentar una cuidadosa revisión bibliográfica de por lo menos 50 referencias.
2. Artículo de investigación científica y tecnológica: documento que presenta, de manera detallada, los resultados originales de proyectos terminados de investigación. La estructura generalmente utilizada contiene cuatro apartes importantes: introducción, metodología, resultados y conclusiones.

3. Artículo de reflexión: documento que presenta resultados de investigación terminada desde una perspectiva analítica, interpretativa o crítica del autor, sobre un tema específico, recurriendo a fuentes originales.

Adicional a estas tipologías, se pueden presentar otro tipo de artículos asociados a procesos de investigación-creación y/o investigación proyectual. En todos los casos se debe presentar la información suficiente para que cualquier investigador pueda reproducir la investigación y confirmar o refutar las interpretaciones defendidas y sea evidente el aporte a la disciplina.

En todos los casos se debe presentar la información suficiente para que cualquier investigador pueda reproducir la investigación y confirmar o refutar las interpretaciones defendidas.

\section{(A) Instrucciones para postular artículos}

Postular el artículo en la página web de la Revista de Arquitectura (Bogotá) y adjuntar comunicación escrita dirigida al editor RevArq_FP00 Carta de originalidad (debidamente firmada por todos los autores en original); de igual manera, se debe diligenciar el formato de hoja de vida RevArq FP01 Hoja de Vida (una por cada autor).

En la comunicación escrita el autor expresa que conoce y acepta la política editorial de la Revista de Arquitectura (Bogotá), que el artículo no está postulado para publicación simultáneamente en otras revistas u órganos editoriales y que no existe conflicto de intereses (ver modelo RevArq FP06 CDI) y que, de ser aceptado, concederá permiso de primera publicación, no exclusiva a nombre de la Universidad Católica de Colombia como editora de la revista.

Los artículos deben tener en cuenta las siguientes recomendaciones:

- En la primera página del documento se debe incluir:

Tírulo: no exceder 15 palabras

Subtítulo: opcional, complementa el título o indica las principales subdivisiones del texto.

Nombre del autor o autores: nombres y apellidos completos o según modelo de citación adoptado por el autor para la normalización de los nombres del investigador. Como nota al pie (máximo 150 palabras): formación académica, experiencia profesional e investigativa, vinculación laboral, código https://orcid.org/, premios o reconocimientos, publicaciones representativas e información de contacto, correo electrónico.

Filiación institucional: debajo del nombre se debe declarar la ins-titución en la cual se desarrolló el producto, de la cual recibió apoyo o aquella que respalda el trabajo investigativo.

Resumen: debe ser analítico, se redacta en un solo párrafo, da cuenta del tema, el objetivo, la metodología, los resultados y las conclusiones; no debe exceder las 150 palabras.

Palabras clave: cinco palabras o grupo de palabras, ordenadas alfabéticamente y que no se encuentren en el título o subtítulo; estas sirven para clasificar temáticamente al artículo. Se recomienda emplear principalmente palabras definidas en el tesauro de la Unesco (http://databases. unesco.org/thessp/), en el tesauro de Arte \& Arquitectura (C) (www.aatespanol.cl), o Vitruvio (http://vocabularyserver.com/vitruvio/)

También se recomienda incluir título, resumen y palabras clave en segundo idioma.

- La segunda página y siguientes deben tener en cuenta:

El cuerpo del artículo se divide en: Introducción, Metodología, Resultados y Discusión de resultados; posteriormente se presentan las Conclusiones, y luego las Referencias bibliográficas y los Anexos (método IMRYD). Las tablas y figuras se deben incorporar en el texto.

Descripción del proyecto de investigación: en la introducción se debe describir el tipo de artículo y brevemente el marco investigativo del cual es resultado y diligenciar el formato (RevArq FP02 Info Proyectos de Investigación).

TEXTO: todas las páginas deben venir numeradas y con el título de artículo en la parte superior de la página. Márgenes de $3 \mathrm{~cm}$ por todos los lados, interlineado doble, fuente Arial o Times New Roman de 12 puntos, texto justificado (Ver plantilla para presentación de artículos). La extensión de los artículos debe ser de alrededor de 5.000 palabras ( \pm 20 páginas, incluyendo gráficos, tablas, referencias, etc.); como mínimo 3.500 y máximo 8.000 palabras. Se debe seguir el estilo vigente y recomendado en el Manual para Publicación de la American Psychological Association (APA). (Para mayor información véase http://www.apastyle.org/)
Citas y notas al pie: las notas aclaratorias o notas al pie no deben exceder cinco líneas o 40 palabras, de lo contrario estas deben ser incorporadas al texto general. Las citas pueden ser:

Corta: (con menos de 40 palabras) se incorporan al texto y pueden ser: textuales (se encierran entre dobles comillas), parafraseo o resumen (se escriben en palabras del autor dentro del texto).

Cita textual extensa: (mayor de 40 palabras) debe ser dispuesta en un renglón y un bloque independiente con sangrías y omitiendo las comillas, no olvidar en ningún caso la referencia del autor (Apellido, año, página).

Referencias: como modelo para la construcción de referencias se emplea el estilo recomendado en el Manual para Publicación de la American Psychological Association (APA) (http://www.apastyle.org/).

Siglas: en caso de emplear siglas en el texto, las figuras o las tablas, se debe proporcionar la equivalencia completa la primera vez que se empleen y encerrarlas entre paréntesis. En el caso de citar personajes reconocidos se deben colocar nombres o apellidos completos, nunca emplear abreviaturas.

Figuras y tablas: las figuras (gráficos, diagramas, ilustraciones, planos, mapas o fotografías) y las tablas deben ir numeradas y contener título o leyenda explicativa relacionada con el tema del artículo, que no exceda las 15 palabras (Figura 1. xxxxx, Tabla 1. xxxx, etc.) y la procedencia (fuente: autor o fuente, año, página). Estas se deben referenciar en el texto de forma directa o entre paréntesis; se recomienda hacerlo con referencias cruzadas.

También se deben entregar en medio digital, independiente del texto, en formatos editables o abiertos. La marcación de los archivos debe corresponder a la incluida en el texto. Según la extensión del artículo se deben incluir de 5 a 10 gráficos. Ver guía para la búsqueda de imágenes de dominio público o bajo licencias Creative Commons (CC).

El autor es el responsable de adquirir los derechos o las autorizaciones de reproducción a que haya lugar para imágenes o gráficos tomados de otras fuentes, así como de entrevistas o material generado po colaboradores diferentes a los autores; de igual manera, se debe garantizar la protección de datos e identidades para los casos que sea necesario.

Fotografía: pueden ser entregadas en original para ser digitalizadas, de lo contrario se deben digitalizar con una resolución igual o superior a 300 dpi para imágenes a color y 600 para escala de grises. Los formatos de las imágenes pueden ser TIFF, PSD o JPG, y deben cumplir con las características expresadas en el punto anterior (figuras).

Planimetría: se debe entregar la planimetría original en medio digital, en lo posible en formato CAD, y sus respectivos archivos de plumas o en PDF; de no ser posible, se deben hacer impresiones en tamaño carta con las referencias de los espacios mediante numeración y lista adjunta. Deben tener escala gráfica, escala numérica, norte, coordenadas y localización. En lo posible, no deben contener textos, achurados o tramas.

Para más detalles, consultar el documento RevArq Parámetros para Autores Descripción en el portal web de la Revista de Arquitectura (Bogotá)

\section{Beneficios}

Como reconocimiento a los autores, se les hará envío postal de dos ejemplares de la edición impresa sin ningún costo y entregada en la dirección consignada en el formato de hoja de vida (RevArq FP01); adicionalmente, se enviará el vínculo para la descarga de la versión digital.

También se enviará una constancia informativa en la que se relaciona a publicación del artículo y, de manera opcional, se pueden detallar las fechas del proceso editorial y el arbitraje realizado. 
La selección de revisores se realiza de acuerdo con los siguientes criterios:

- Afinidad temática.

- Formación académica.

- Experiencia investigativa y profesional.

- Producción editorial en revistas similares o en libros resultado de investigación.

El proceso de arbitraje se basa en los principios de equidad e imparcialidad, y en los criterios de calidad y pertinencia.

El desarrollo de la revisión se realiza según el formato (RevArq FP10 Evaluación de artículos) y las observaciones que el revisor considere necesarias en el cuerpo del artículo. En cualquiera de los conceptos que emita el revisor (Aceptar, Publicable con modificaciones, Reevaluable o No publicable), y como parte de la labor formativa y de comunidad académica, el revisor hará sugerencias para mejorar el documento. El revisor podrá solicitar una nueva relectura del artículo después de los ajustes realizados por el autor.

El revisor también deberá diligenciar el formato RevArq FP01 Hoja de Vida, con el fin de certificar y soportar el proceso de revisión ante los SIR que así lo soliciten.

En el proceso de arbitraje se emplea el método doble ciego, los nombres del revisor no serán conocidos por el autor y viceversa. Con el fin de garantizar el anonimato del autor, al artículo postulado se le han podido suprimir nombres, instituciones o imágenes que puedan ser asociadas de manera directa al autor.

Aunque se procura el anonimato, una vez recibida la invitación como par revisor del artículo, el revisor debe cerciorarse de que no exista conflicto de intereses (CDI) o alguna limitante que afecte la revisión o que pueda ser vista como tal (lazos familiares, amistad o enemistad, vínculos contractuales o laborales, posiciones éticas, etc.), de presentarse esta situación se notificara al editor. (Ver modelo RevArq FP06 CDI).

Dada la confidencialidad del proceso de revisión, y considerando los derechos de autor y de propiedad intelectual que pueda haber sobre el material que se entrega, el revisor se compromete a mantener en absoluta reserva su labor, a limitar el uso de la obra entregada solo para el propósito designado y a devolver la documentación remitida una vez concluya la actividad.

El tiempo establecido para las revisiones de pares es de máximo un mes a partir de la confirmación de la recepción de la documentación. Ese plazo podrá ser modificado de mutuo acuerdo entre el editor y el revisor, siempre y cuando no afecte la periodicidad de la revista, la impresión o el tiempo para emitir una respuesta al autor.

Los revisores se acogerán a "COPE Ethical Guidelines for Peer Reviewers" de COPE.

\section{Beneficios}

Como retribución a los revisores se les hará envío postal de un ejemplar de la edición impresa sin ningún costo y entregada en la dirección consignada en el formato de hoja de vida. También, si es de interés para el revisor, podrá hacer la solicitud de alguna de las publicaciones editadas y presentes en el catálogo de publicaciones de la UNIVERSIDAD CATÓLICA DE COLOMBIA, previa aprobación de la Editorial y sujeto a la disponibilidad.

Si lo desea tendrá derecho a una constancia de la colaboración en la revisión de artículos, la cual solo contendrá el periodo en el cua se realizó la actividad. También tendrá la posibilidad de aceptar o no la publicación de su nombre, nacionalidad y nivel máximo de formación en la página web de la Revista de Arquitectura (Bogotá) en su calidad de colaborador.

\section{A Proceso de revisión por pares}

Luego de la postulación del artículo, el editor de la Revista de Arquitectura (Bogotá) selecciona y clasifica los artículos que cumplen con los requisitos establecidos en las directrices para los autores. El editor podrá rechazar en primera instancia artículos, sin recurrir a un proceso de revisión, si los considera de baja calidad o por presentar evidencias de faltas éticas o documentación incompleta.

Los artículos se someterán a un primer dictamen del editor, de los editores de sección y del Comité Editorial, teniendo en cuenta:

- Afinidad temática, relevancia del tema y correspondencia con las secciones definidas.

- Respaldo investigativo.

- Coherencia en el desarrollo del artículo, así como una correcta redacción y ortografía.
- Relación entre las figuras y tablas con el texto del artículo.

En esta revisión se verificará el nivel de originalidad mediante el uso de software especializado (Ithenticate o similar) y recursos digitales existentes para tal fin, también se observará la coherencia y claridad en los apartados del documento (modelo IMRYD) la calidad de las fuentes y la adecuada citación, esto quedará consignado en el formato (RevArq FP09 Revisión de artículos); esta información será cargada a la plataforma de gestión editorial y estará a disposición del autor.

En caso de que el artículo requiera ajustes preliminares, será devuelto al autor antes de ser remitido a revisores. En este caso, el autor tendrá veinte días para remitir nuevamente el texto con los ajustes solicitados.

Después de la preselección se asignan mínimo dos revisores especializados, quienes emitirán su concepto utilizando el formato (RevArq FP10 Evaluación de artículos) y las anotaciones que consideren oportunas en el texto; en esta etapa se garantizará la confidencialidad y el anonimato de autores y revisores (modalidad doble ciego)

Del proceso de revisión se emite uno de los siguientes conceptos que será reportado al autor:

- Aceptar el envío: con o sin observaciones.

- Publicable con modificaciones: se podrá sugerir la forma más adecuada para una nueva presentación, el autor puede o no aceptar las observaciones según sus argumentos. Si las acepta, cuenta con quince días para realizar los ajustes pertinentes.

- Reevaluable: cumple con algunos criterios y debe ser corregido. Es necesario hacer modificaciones puntuales y estructurales al artículo. En este caso, el revisor puede aceptar o rechazar hacer una nueva lectura del artículo luego de ajustado.

- No publicable: el autor puede volver a postular el artículo e iniciar nuevamente el proceso de arbitraje, siempre y cuando se evidencien los ajustes correspondientes.

En el caso de presentarse diferencias sustanciales y contradictorias en los conceptos sobre la recomendación del revisor, el editor remitirá el artículo a un revisor más o a un miembro del Comité Editorial quien podrá actuar como tercer árbitro, con el fin de tomar una decisión editorial sobre la publicación de artículo.

Los autores deberán considerar las observaciones de los revisores o de los editores, y cada corrección incorporada u omitida debe quedar justificada en el texto o en una comunicación adjunta. En el caso que los autores omitan las indicaciones realizadas sin una argumentación adecuada, el artículo será devuelto y no se dará por recibido hasta que no exista claridad al respecto. El editor respetará la independencia intelectual de los autores y a estos se les brindará el derecho de réplica en caso de que los artículos hayan sido evaluados negativamente y rechazados. Los autores, con su usuario y contraseña, podrán ingresar a la plataforma de Gestión Editorial, donde encontrarán los conceptos emitidos y la decisición sobre el artículo.

El editor y el Comité Editorial se reservan el derecho de aceptar o no la publicación del material recibido. También se reservan el derecho de sugerir modificaciones de forma, ajustar las palabras clave o el resumen y de realizar la corrección de estilo. El autor conocerá la versión final del texto antes de la publicación oficial del mismo.

Cuando un artículo es aceptado para su publicación, el autor debe firmar la autorización de reproducción (RevArq FP03 Autorización reproducción). Para más información ver: Política de derechos de autor

\section{Notas aclaratorias:}

La Revista de Arquitectura (Bogotá) busca el equilibrio entre las secciones, motivo por el cual, aunque un artículo sea aceptado o continúe en proceso de revisión, podrá quedar aplazado para ser publicado en un próximo número; en este caso, el autor estará en la posibilidad de retirar la postulación del artículo o de incluirlo en el banco de artículos del próximo número.

El editor y los editores de sección de la Revista de Arquitectura (Bogotá) son los encargados de establecer contacto entre los autores y revisores, ya que estos procesos se realizan de manera anónima.
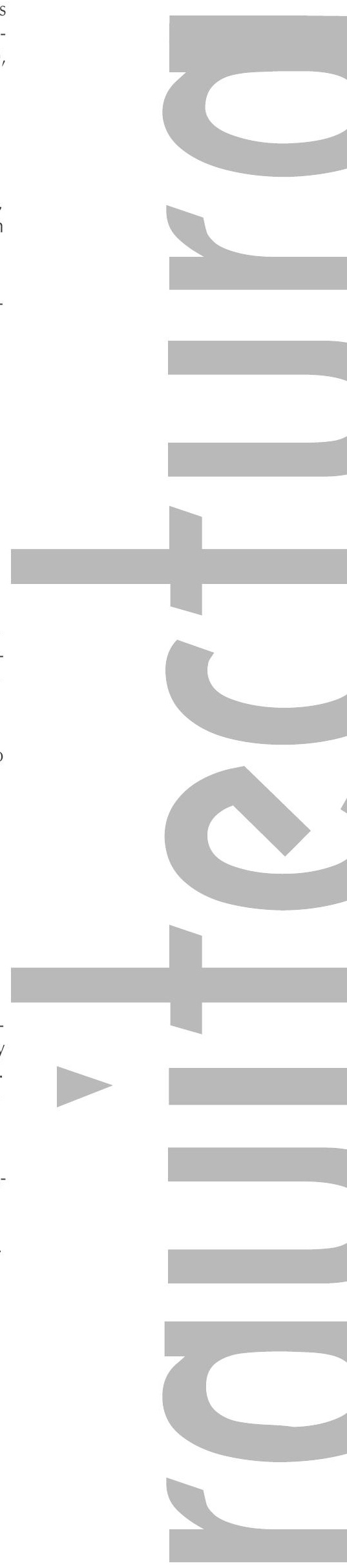

\section{.}

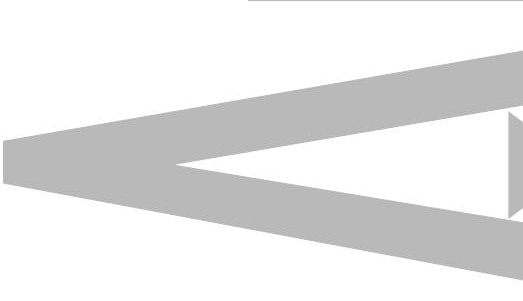


Los artículos científicos como herramienta de aprendizaje en las escuelas de arquitectura

نं Scientific articles as a learning tool in architecture schools

$\ll \quad$ Os artigos científicos como ferramenta de aprendizagem

nas escolas de arquitetura

Carolina Rodriguez-Ahumada

Paisaje urbano y espacio público como expresión 으 de la vida cotidiana

Urban landscape and public space as an expression of everyday life

نั Paisagem urbana e espaço público como expressão da vida cotidiana

Habitar la quebrada: conformación de gradientes en las trazas 을 vernaculares de los sectores altos de Valparaíso

Inhabiting the ravine: Gradient configuration in the vernacular layouts of the

¿ higher sectors of Valparaíso

Habitar a quebrada: conformação de níveis nos traçados vernaculares dos setores altos de Valparaíso

\section{Omar Eduardo Canete-Islas}

Juan Luis Moraga-Lacoste

Felipe Mateo López-Flores

Láminas cilíndricas en la arquitectura colombiana del siglo $X X$ Cylindrical shells in Colombian architecture in the 20th century

Estruturas laminares cilíndricas na arquitetura colombiana do século $X X$ 这 Jorge Galindo-Díaz

Retórica simbólica en el espacio arquitectónico. Una mirada antropológica de la casa en la sobremodernidad

in Symbolic Rhetoric in the Architectural Space: An Anthropological View of the

ن House in the Age of Supermodernity

Retórica simbólica no espaço arquitetônico. Um olhar antropológico da casa na sobremodernidade

\section{Eska Elena Solano-Meneses}

Ecoenvolventes: análisis del uso de fachadas ventiladas en clima ㅈ cálido-húmedo

نं Eco-friendly coverings: Analysis of the use of ventilated facades in hot, humid

ن⿺ weather

Ecoenvolventes: análise do uso de fachadas ventiladas em clima quente úmido

Sara Luciani-Meía

Rodrigo Velasco-Gómez

Roland Hudson

Estrategias metodológicas de análisis urbano frente al cambio œ climático. Matriz para el diseño adaptativo en asentamientos $\stackrel{\infty}{\text { informales }}$

Methodological strategies for urban analysis in the face of climate change. An adaptive design matrix for informal settlements

Estratégias metodológicas de análise urbana ante mudanças climáticas. Matriz para o desenho adaptativo em assentamentos informais

Adriana Patricia López-Valencia

Muro panel térmico estructural compuesto en guadua y - cartónModelo experimental aplicado al clima de la zona cafetera

․ Structural thermal panel wall composed of bamboo and cardboard.

Experimental model applied to the climate of the Coffee Region

$\ltimes$ Muro painel térmico estrutural composto de bambu e papelão. Modelo experimental aplicado ao clima da zona cafeeira

\section{Renato Cassandro-Cajiao}

Continuidad y transformaciones de modelos pedagógicos en la École Polytechnique (1867-1910)

으 Continuity and transformations of teaching models at the École Polytechnique

二 (1867-1910)

ن Continuidade e transformações de modelos pedagógicos na École

¿ Polytechnique (I867-1910) 